\title{
Anchors Aweigh: The Sources, Variety, and Challenges of Mission Drift
}

\begin{tabular}{|c|c|}
\hline Journal: & Academy of Management Review \\
\hline Manuscript ID & AMR-2017-0254-STFSTR.R2 \\
\hline Manuscript Type: & STF Strategy \\
\hline Theoretical Perspectives: & Organizational Adaptation, Strategic Mission/Vision/Goals, Performance \\
\hline Topic Areas: & $\begin{array}{l}\text { Strategic change processes }<\text { Strategic Management Process }<\text { Business } \\
\text { Policy and Strategy, Managerial and organization cognition (General) }< \\
\text { Managerial and Organizational Cognition, Identity and Categorization }< \\
\text { Organization and Management theory }\end{array}$ \\
\hline Abstract: & $\begin{array}{l}\text { The growing number of studies which reference the concept of mission } \\
\text { drift imply that such drift is an undesirable strategic outcome related to } \\
\text { inconsistent organizational action, yet beyond such references little is } \\
\text { known about how mission drift occurs, how it impacts organizations, and } \\
\text { how organizations should respond. Existing management theory more } \\
\text { broadly offers initial albeit equivocal insight for understanding mission } \\
\text { drift. On the one hand, prior studies have argued that inconsistent or } \\
\text { divergent action can lead to weakened stakeholder commitment and } \\
\text { reputational damage. On the other hand, scholars have suggested that } \\
\text { because environments are complex and dynamic, such action is } \\
\text { necessary for ensuring organizational adaptation and thus survival. In } \\
\text { this study, we offer a theory of mission drift that unpacks its origin, } \\
\text { clarifies its variety, and specifies how organizations might respond to } \\
\text { external perceptions of mission drift. The resulting conceptual model } \\
\text { addresses the aforementioned theoretical tension and offers novel } \\
\text { insight into the relationship between organizational actions and identity. }\end{array}$ \\
\hline
\end{tabular}

\section{SCHOLARONE ${ }^{\text {TM }}$ Manuscripts}




\title{
Anchors Aweigh: The Sources, Variety, and Challenges of Mission Drift
}

\author{
Matthew G. Grimes \\ University of Cambridge \\ Cambridge, UK \\ m.grimes@jbs.cam.ac.uk
}

Trenton A. Williams

Indiana University

Bloomington, Indiana

trenwill@iu.edu

Eric Yanfei Zhao

Indiana University

Bloomington, Indiana

ericzhao@indiana.edu

Accepted for publication in the Academy of Management Review

\begin{abstract}
Acknowledgments
We would like to extend our gratitude to Associate Editor Kyle Mayer and the three anonymous reviewers who pushed our writing forward. We also wish to acknowledge the feedback we received from Jeff McMullen on an earlier draft as well as the efforts of our graduate assistant, Phanindra Thadakamadla, who compiled many of the contemporary examples found throughout this paper.
\end{abstract}




\title{
Anchors Aweigh: The Sources, Variety, and Challenges of Mission Drift
}

\begin{abstract}
The growing number of studies which reference the concept of mission drift imply that such drift is an undesirable strategic outcome related to inconsistent organizational action, yet beyond such references little is known about how mission drift occurs, how it impacts organizations, and how organizations should respond. Existing management theory more broadly offers initial albeit equivocal insight for understanding mission drift. On the one hand, prior studies have argued that inconsistent or divergent action can lead to weakened stakeholder commitment and reputational damage. On the other hand, scholars have suggested that because environments are complex and dynamic, such action is necessary for ensuring organizational adaptation and thus survival. In this study, we offer a theory of mission drift that unpacks its origin, clarifies its variety, and specifies how organizations might respond to external perceptions of mission drift. The resulting conceptual model addresses the aforementioned theoretical tension and offers novel insight into the relationship between organizational actions and identity.
\end{abstract}

Keyword list: mission, organizational identity, adaptation, values 


\section{INTRODUCTION}

Scholars have frequently assumed that an organization's actions proceed directly from the influence exerted by its identity (i.e., the attributes deemed central and distinctive to the organization; Dutton \& Penner, 1993; Whetten, 2006; Whetten \& Mackey, 2002). To the extent that an organization's identity may change over time, once established or re-established, that identity is presumed to both constrain and enable action by setting new bounds on what is deemed appropriate (Gioia, Price, Hamilton, \& Thomas, 2010; Gioia, Schultz, \& Corley, 2000). However, a number of recent studies have argued and shown that actions - even those that might be considered strategic in nature-may sometimes diverge from an organization's identity (Battilana \& Lee, 2014; Harrison, Ashforth, \& Corley, 2009; Kraatz, Ventresca, \& Deng, 2010). This divergence suggests that the presumed contiguous relationship between an organization's identity and its actions might not be as straightforward as originally conceived.

In this article, we argue that an organization's mission serves as a socio-cognitive bridge between its identity and its actions by specifying why the organization should exist and how it should act (i.e., purpose), thereby focusing members' attention and intentions in such a way that actions proceed from identity (Crotts, Dickson, \& Ford, 2005). In many cases, external audiences become aware of organizations' missions by way of published 'mission statements' (Blair-Loy, Wharton, \& Goodstein, 2011) or by way of inferences based on consistent patterns of observable action and communications, which then shape those audiences' perceptions of what is central and distinctive about the organization (i.e., the organization's image ${ }^{1}$ ). Accordingly, an organization's mission not only serves as the socio-cognitive bridge between its identity and its actions but also

\footnotetext{
${ }^{1}$ Organizational image refers to how outsiders view what is central and distinctive about an organization (Elsbach \& Kramer, 1994; Gioia, et al., 2010). This term "image", however, has also occasionally been used to refer to how organizational members believe others view the organization (Dutton \& Dukerich, 1991) as well as how organizational leaders attempt to present the organization's identity to outsiders (Whetten, et al., 1992). Here, we use the concept of organizational image exclusively to refer to the organization's externally perceived identity.
} 
between its image and those actions. Notably then, when an organization's actions are inconsistent over time, this might increase the likelihood that audiences perceive discontinuity between those actions and the organization's image — a perceived discontinuity we call mission drift.

In organizational scholarship, references to mission drift have appeared most frequently in studies of social enterprise, wherein commitments to positive social change are taken for granted and any perceived shift away from social objectives is largely treated as a liability (Battilana \& Lee, 2014). For instance, in a New York Times editorial, Nobel Peace Prize winner Muhammad Yunus accused several microfinance organizations of demonstrating "a worrying "mission drift"' - a perceived shift toward the pursuit of profitability that was disconnected from how Yunus perceived their organizational identity of serving the poor and promoting social inclusion (Yunus, 2011). Building on this, Battilana and Lee (2014) called for further research on mission drift, suggesting that it is an important challenge of our time and inherent to a broad range of organizations that seek to combine multiple objectives. Given the increased demand for even traditional firms to embrace multiple objectives (Hollensbe, Wookey, Hickey, George, \& Nichols, 2014; McMullen \& Warnick, 2016), as well as increased pressures from a rapidly changing competitive landscape (Bakker \& Shepherd, 2017), mission drift is front and center as an emerging strategic challenge - one with relevance beyond the context of social entrepreneurship. For example, as social media has risen in prominence, politicians, the media, and even former executives have expressed growing concern regarding Facebook's unintended impacts on society, which are perceived as linked to distortions in its ad-based revenue model that prompted the organization to deviate from its original identity claims (Loizos, 2017). Facebook CEO and coFounder Mark Zuckerberg has consistently stated that Facebook "was [initially] built to accomplish a social mission — to make the world more open and connected" (Chaykowski, 2017). 
However, a recent investigative report (Dance, Confessore, \& LaForgia, 2018) catalogs how Facebook's efforts to make the world more "open and connected" drifted, creating massive privacy issues. Dance and colleagues (2018) found that as Facebook sought to "become the world's dominant social media service, it struck agreements allowing phone and other device makers access to vast amounts of its users' personal information ... [resulting in cell-phone] users [being] turned into data dealers, unknowingly and unwillingly." The unauthorized sharing of user data, along with Facebook's role in recent U.S. elections has resulted in intense public criticism. In response to such criticism, Mark Zuckerberg and the leadership at Facebook recently announced a new mission statement for Facebook, which is to "[g]ive people the power to build community and bring the world closer together" (Chaykowski, 2017). This revised mission statement has been followed by an expansive advertisement campaign to address Facebook's "serious image issue that it has substantially strayed from its initial intentions," where Facebook admits that it "needs to do better ... with spam, clickbait, fake news, and data misuse" (Domanski, 2018)—in essence, communicating its efforts to bring actions back into alignment with its identity.

Despite growing recognition of the practical and theoretical importance of mission drift and the potential challenges it poses to organizations, existing scholarship offers limited clarity into the sources, attributes, and consequences of mission drift and how, in turn, organizations might respond to such drift. As a result, we know little about how mission drift might ultimately affect organizations. Moreover, because prior studies have restricted their examination of mission drift to the context of social enterprises, we see an opportunity to broaden the focus beyond the idiosyncratic tensions that characterize drift in social enterprises to instead consider the potential challenges (and, perhaps, opportunities) that mission drift poses for all organizations.

To fill these research gaps and expand on the scope of inquiry on mission drift, we ground 
our theorizing in existing studies of organizational identity and organizational adaptation (Brown \& Eisenhardt, 1997; Whetten, 2006). Although this body of literature has yet to explicitly consider the concept of mission drift, it does provide some initial basis for beginning to theorize the relationship between such drift and its implications for organizations. On the one hand, research that takes a social actor view of organizational identity presumes the need for continuity, not just with regard to identity over time, but also with regard to the alignment between such identity and the organization's strategies and actions (King, Clemens, \& Fry, 2010; King \& Whetten, 2008). Failure to align organizational identity and action might thus cause external audiences to call into question the organization's authenticity (Whetten, 2006). Other studies, however, suggest the need for organizations' adaptation to the uncertain, complex, and ever-changing values in a given context (Anderson, 1999; Davis, Eisenhardt, \& Bingham, 2009; Greenwood, Raynard, Kodeih, Micelotta, \& Lounsbury, 2011; Sirmon, Hitt, \& Ireland, 2007). In this case, although an organization's actions might diverge from its identity, those actions might also help the organization appear more responsive to its environment (Suchman, 1995). In other words, although mission drift may present clear liabilities for organizations, it also may offer unexpected benefits under particular conditions.

Considering the potential for such countervailing effects, we develop a socio-cognitive framework of organizational mission drift, theorizing its origins and variety as well as how organizations might respond. Taken together, our theory and model offer novel insight into how inconsistent organizational actions lead to perceived mission drift, and how these perceptions may shape subsequent organizational efforts to realign the organization's image and its actions. In developing these arguments, we challenge and extend existing scholarship on both organizational identity and organizational adaptation. First, our model challenges existing research that has 
exclusively regarded mission drift as a negative organizational outcome resulting from organizational mismanagement (Battilana \& Lee, 2014; Yunus, 2011). We suggest that although shifts in an organization's actions away from its image can generate negative appraisals, such shifts can ultimately prove advantageous to the organization if and when those shifts are coupled with appropriate and skillfully executed mission work. Second, our model challenges extant research on the process by which organizational identities are revised (Corley \& Gioia, 2004; Gioia et al., 2010). With few exceptions, these studies have viewed shifts in organizational identity as deliberate and planned. Our arguments challenge these assumptions, suggesting that these shifts also may occur by way of organizations' efforts to realign their image with their actions following emergent perceived discontinuities between the two. Finally, our paper contributes to the growing number of studies that consider the importance of values within and surrounding organizations (Besharov, 2014; Gehman, Treviño, \& Garud, 2013; Kraatz \& Flores, 2015; Krygier, 2015; Selznick, 2008). Specifically, our focus on mission drift shifts attention away from the view of organizations as governance mechanisms for administering organizational values toward the view of organizations as equilibrating mechanisms that must coordinate and balance efforts to uphold existing organizational values while also responding to challenges associated with values-based complexity in and around those organizations.

\section{A SOCIO-COGNITIVE MODEL OF MISSION DRIFT AND ORGANIZATIONS' RESPONSES}

Before proceeding to theoretically ground and develop our proposed concepts and relationships, we illustrate our model in Figure 1 to offer a preview and structure for our theorizing. Although we briefly introduce and define a number of theoretical relationships here which comprise our model, the remainder of the article is set up to offer more in-depth justification for each of these relationships. As illustrated in the model, values-based complexity, operating at the 
societal, field, and organizational levels (Greenwood et al., 2011; Kraatz \& Block, 2017), can result in inconsistent organizational action (i.e., actions that diverge from prior observable patterns of organizational action). By values-based complexity, we refer to the prevalence of multiple, independent yet interacting, and continuously changing values amidst society, organizational fields, and within organizations. Inconsistent actions, we argue, can vary both in the degree to which they are coordinated (i.e., the degree of design and oversight of tasks and activities to achieve a common outcome; March \& Simon, 1958; Miles, Snow, Meyer, \& Coleman, 1978) as well as the degree to which they are inconsistent with core (versus peripheral) aspects of the organizations' business models (Hannan, Baron, Hsu, \& Koçak, 2006). The type of inconsistent organizational action depends on the degree to which values-based complexity is accompanied by organizational mindfulness ("rich awareness of discriminatory detail generated by organizational processes;" Weick \& Sutcliffe, 2006: 516) and resource discretion (i.e., the organizational leaders' latitude in allocating resources; Hambrick \& Finkelstein, 1987). When inconsistent organizational action occurs, we argue that this encourages external perceptions of mission drift, which vary with regard to audience evaluations of the organization's authenticity and responsiveness. Finally, our model depicts how organizations likely respond to perceptions of mission drift by way of "mission work" (i.e., symbolic and material efforts to manage impressions regarding the divergence between organizational image and organizational action).

------Insert Figure 1 about here------

\section{THEORETICAL GROUNDING}

Although the concept of organizational mission is largely taken-for-granted as a common part of speech within strategic management parlance, it has been severely undertheorized to date (Bart \& Baetz, 1998; Pearce \& David, 1987). To the extent that management scholars have 
considered this concept, they have done so primarily by studying the specific statements organizations offer to publicize those missions - i.e., mission statements (Bartkus \& Glassman, 2008). These statements are largely understood as capturing the organizations' aspirations regarding the values and the broad set of purposes they wish to enact (Hollensbe et al., 2014). For instance, the healthcare organization Bristol-Myers Squibb Company (2017) articulates its mission statement, "To discover, develop, and deliver innovative medicines that help patients prevail over serious diseases." Alternatively, the financial institution Citigroup (2017) states its mission as, "We responsibly provide financial services that enable growth and economic progress." By publicizing such statements, these and other organizations attempt to formalize the relationship between the values they perceive as central and distinctive and their organizations' actions. For example, Microsoft's prior mission statement reiterated this relationship, ending with the imperative, "Everything we do reflects this mission and the values that make it possible" (Lachowski, 2012). In this way, an organization's mission is meant to orient its members' attention and intentions toward actions consistent with the values underpinning its identity. Moreover, because these statements are now regularly made public on organizations' websites, they formalize not only the relationship between organizations' identities and their actions but also between those organizations' images and their actions. In other words, an organization's mission inasmuch as it is externalized by way of explicit statements or observable, patterned actions and communications over time also establishes audiences' expectations regarding what types of actions are appropriate for that organization to undertake.

Like the concept of organizational mission, the related notion of mission drift remains similarly underdeveloped within the management literature. In the case of mission drift, the concept has appeared only recently, most notably in the literature on social enterprises - namely, 
organizations seeking to solve social problems through commercial means (see Battilana \& Lee, 2014 for review). According to this research, mission drift occurs when there is an emergent change in the organizations' actions that deviates symbolically or materially from that organization's original and perceived identity (Armendáriz \& Szafarz, 2009; Bennett \& Savani, 2011). Many related studies have thus been quick to highlight the problematic consequences of drift for social ventures, such as microfinance organizations. For example, Battilana and Dorado (2010) found that actors within microfinance institutions can (and often do) switch their priorities toward either banking- or social development-related objectives with relative ease, posing a threat to the original purpose of these organizations and stakeholders' perceptions of this purpose. Similarly, Armendáriz and Szafarz (2009) argued that microfinance organizations drift by increasing loan sizes, thereby shifting toward servicing wealthier clients rather than the impoverished individuals they initially claim to help (see also Wry \& Zhao, 2018).

Despite the growing number of references to the concept of mission drift, it remains poorly defined and restricted to the study of social enterprise. Therefore, we see an opportunity to extend theory by first, grounding the concept of mission drift in both prior research on organizational identity as well as organizational adaptation and second, extending the applicability of the concept to the study of all organizations. Specifically, because the concept of mission drift invokes issues of organizational alignment, prior research on both organizational identity and adaptation likely offer important bases for understanding the phenomenon. On the one hand, research on organizational identity would suggest that mission drift might be best understood in terms of perceived organizational authenticity - i.e., the perceived alignment between organizational action and organizational identity. On the other hand, research on organizational adaptation would suggest that mission drift might be best understood in terms of perceived organizational 
responsiveness-i.e., the perceived alignment between the organization's actions and its environment.

\section{Organizational Identity and Mission Drift}

An organization's identity is comprised of particular features (e.g., values) that are recognized as central, distinctive, and exhibiting some degree of continuity over time (Albert \& Whetten, 1985; Gioia, Patvardhan, Hamilton, \& Corley, 2013). Given their centrality, the values associated with an organization's identity are thought to motivate and structure subsequent organizational action. For instance, because early claims by founders as to the identity of their organizations tend to guide early policies and routines, the organizations' actions likely replicate and even reinforce those routines over time (Gioia et al., 2010; Whetten \& Mackey, 2002). Moreover, because organizational identities are thought to support and increase the self-esteem of members (Brown \& Starkey, 2000), scholars have argued that "individuals have a stake in directing organizational action in ways that are consistent with what they believe is the essence of the organization" (Dutton \& Dukerich, 1991: 550)

Yet, despite these arguments substantiating links between organizational identity and action, empirical evidence suggests that organizations' do occasionally act in ways that appear inconsistent with their organizations' identities. For instance, Harrison, Ashforth, and Corley (2009) cite the example of JetBlue, who at the time described their mission as "bringing humanity back to air travel." Yet despite this stated mission, they were perceived as consistently mistreating their passengers, resulting in falling stock prices and estimated costs of close to $\$ 30$ million. Similarly, the Walt Disney Company has been consistently well known for its animated, familyfriendly films. When releasing the film Trenchcoat in the early 1980s, Disney saw box-office success but suffered criticism that the adult-themed film was inappropriate for Disney. Such 
examples also highlight the problem associated with such inconsistency-when organizations are perceived as acting "out of character", this introduces questions of the organizations' authenticity. Prior studies specifically suggest that questions regarding an organization's authenticity can arise because of perceived discontinuities between an organization's actions and the expectations audiences form by way of the organization's normative commitments and claims (Hannan et al., 2006). As summarized by Kraatz and Block (2017: 24), “Organizations are... required to make normative commitments and claims (i.e., to say what they value and what they contribute to society). These value claims become organization-specific standards against which their subsequent actions are judged." Therefore, when organizations and their leaders espouse an identity and a corresponding set of values, they form an implicit contract with key stakeholders like customers, suppliers, and regulators (De Luque, Washburn, Waldman, \& House, 2008; Harrison et al., 2009; Rousseau, 1995), establishing expectations for firm behavior and performance (Whetten \& Mackey, 2002). As consensus forms around those expectations, this consensus constitutes the organization's image, and thus inconsistent organizational action might be viewed as a violation of the organization's image and raise concerns of inauthenticity (Bosse, Phillips, \& Harrison, 2009).

\section{Organizational Adaptation and Mission Drift}

In contrast to the literature on identity, research on organizational adaptation would suggest a notably different perspective on mission drift, given longstanding empirical evidence regarding the need for organizations to remain responsive to external pressures for change (Brown \& Eisenhardt, 1997; Miller \& Friesen, 1984; Teece, Pisano, \& Shuen, 1997). Viewed in this light, mission drift could also be seen as a form of organizational responsiveness, wherein deviance from the original identity is perceived as creating requisite variety, thus serving to better position the 
firm for long-term sustainability. As organizations face "high-velocity environments" with increasing complexity (Bourgeois \& Eisenhardt, 1988; Greenwood et al., 2011), competitive advantage is viewed as stemming not from an organization's alignment with prior articulations of its identity but rather from its alignment with constantly shifting environmental expectations and demands (Eisenhardt \& Martin, 2000). In returning to the Disney example, Walt Disney Co. not only faced pressures to act in ways consistent with its image as a family-friendly entertainment company. It also faced shifting cultural and market values to which it needed to respond. As the LA Times wrote in response to Disney's release of a PG-13 rated movie, "Industry experts see Disney's decision to release a PG-13 movie under its legendary family film banner as recognition of the changing cultural, technological and box-office realities that influence today's action-movie market" (Eller, 2003).

Given the potential for mission drift to both undermine an organization's authenticity and promote perceptions of its responsiveness, this ostensible tension suggests the possibility that there may be different types of mission drift as well as different organizational conditions that, together, may account for the aforementioned theoretical tension. In the following sections, we explore the origins, organizational contingencies, and consequences of mission drift and clarify its various types. We then theorize about how organizations might respond to these different types of mission drift.

\section{THE ORIGIN OF MISSION DRIFT AND ITS ORGANIZATIONAL CONTINGENCIES}

\section{How Values-Based Complexity Encourages Inconsistent Organizational Action}

Values refer to "conceptions of the good-ideals about what is worth having, doing, and being" (Kraatz \& Block, 2017: 20), and as such, they serve as a critical feature of both organizations and institutional environments (Selznick, 1957, 2000). Values play an essential role 
in the context of organizing in that they comprise, in part, organizations' identities, providing direction, meaning, and purpose for members and their actions (Kraatz \& Flores, 2015). In particular, values have been suggested to shape organizational actions through their influence on organizational members' intentions and attention. Guided by certain values, organizational members form intentions, which correspond with desired future positions for their organizations and establish the criterion upon which the organizations chart and gauge their progress (Hamel \& Prahalad, 2005). Moreover, given cognitive limitations of organizations and their members, values serve as a means for filtering members' attention, encouraging greater awareness of some environmental cues in lieu of others. As such, to the extent that organizations embrace and are exposed to a highly stable, coherent, and limited set of values, those organizations' members experience clearer guidance regarding which priorities and actions are worth considering.

Yet as is the case for most if not all organizations, instead of being guided by a small number of stable and unambiguous values, organizations are instead confronted by multiple coexisting, dynamic, and often times incompatible values. Moreover, such values-based complexity tends to exist and impinge on organizations from both external and internal sources. Externally, values are constituted through multiple institutional logics - the set of material practices and symbolic constructions associated with various institutional orders (e.g., the state, religion, profession, family, market) that serve as organizing principles and thus shape organizations and their actions (Friedland \& Alford, 1991; Thornton, Ocasio, \& Lounsbury, 2012). In many cases, these different institutional orders and the associated organizing principles (i.e., logics) prescribe values that are occasionally incompatible (Battilana \& Dorado, 2010). Organizations are also affected by values-based complexity which exists within organizational fields. Specifically, organizations span a variety of commercial and public domains, within which the key suppliers, 
resource and product consumers, regulatory agencies, and producers operate and interact. Numerous studies of different organizational fields - such as equity markets (Zajac \& Westphal, 2004), mutual funds (Lounsbury, 2007), banking (Marquis \& Lounsbury, 2007), liberal arts colleges (Kraatz et al., 2010), higher education publishing (Thornton \& Ocasio, 1999), modern architecture (Jones, Maoret, Massa, \& Svejenova, 2012), health care organizations (Scott, 2000), and French cuisine (Rao, Monin, \& Durand, 2003) — highlight the ways that the values which become taken-for-granted within those fields create pressures of conformity for the embedded organizations. However, Greenwood and colleagues (2011) argue that within such fields, fragmentation (i.e., the number of uncoordinated constituents upon which an organization is dependent for legitimacy or material resources), formal structuring (i.e., whether stakeholder demands are formally or informally organized), and centralization (i.e., the hierarchical power structure of institutional constituents) all independently and jointly affect the nature and level of complexity imposed upon organizations by their fields.

Moreover, organizations are often multiply embedded, operating simultaneously within different fields and societies, where there are different sets of values that introduce confusion about the commitments, responsibilities, and duties of those organizations and their members (Gehman \& Grimes, 2017; Marquis \& Tilcsik, 2016). In addition, the values which characterize those fields are not stable, often generating newfound pressures to adopt emerging technologies and innovations that encourage consequential shifts in the embedded organizations (Kraatz et al., 2010; Moore \& Kraatz, 2011). For example, Kraatz and colleagues (2010) examined the adoption of enrollment management among liberal arts colleges and found that the "mundane innovation" of enrollment management technologies exposed liberal arts colleges to values-based complexity. That is, adopting the system exposed the colleges to unanticipated market values, which collided 
with longstanding values associated with academic instruction and support.

While values-based complexity is prevalent among societies and organizational fields, it is also pervasive within organizations due to the diverse actors that comprise those organizations. Some scholars have thus referred to organizations as complex systems, which are "comprised of numerous interacting agents, each of which acts on the basis of local knowledge or rules" (Plowman et al., 2007: 519). The (potentially) divergent set of rules, needs, and interests within an organization can ultimately create competing factions, where actors "intervene at different phases of the evaluation-choice-action [organizing] process" (Thietart \& Forgues, 1995: 22). In this way, organizations serve as sites of contested power (Dyck, 1997; Perrow, 1972; Pfeffer, 1992). Organizations in this sense are tools that get mobilized toward particular ends, and those ends are determined by the values of those who exert the greatest influence within the organization. As Perrow (1972: 16) notes, the "resources and the goals of the organization are up for grabs, and people grab for them continually." Moreover, these contests for power and influence within organizations extend beyond the goals of the organizations to the implementation of those goals. Of course, if everyone in the organization shares the same values, consensus could be easily derived for those means and ends. However, this is rarely the case — organizations instead tend to feature highly varied and dynamic values amidst their membership. Pfeffer (1992), for instance, discusses how values-based complexity was characteristic throughout Ford Motor Company's history, wherein the engineering group consistently developed new automotive innovations yet the company refused to adopt those innovations due to the divergent values of those within the finance group.

While these prior studies point to the various cultural and relational determinants of valuesbased complexity within and surrounding organizations, we complement this line of research by 
examining how such complexity—regardless of its external or internal origins - can encourage inconsistent organizational action through its disruptive effect on members' attention and intentions. In settings characterized by values-based complexity, organizations can face growing internal and external tensions as they seek to maintain alignment between their identity and actions while simultaneously responding to environmental shifts effectively (Battilana \& Lee, 2014). This balance becomes increasingly difficult when there are multiple and competing values among important organizational audiences, making it difficult "to interpret organizational reality, what constitutes appropriate behavior, and how to succeed" (Thornton, 2004: 70).

Different value prescriptions may compete for attention with the organization, pushing organizational resources and efforts towards divergent goals and interests (Ocasio, 1997; Thornton, 2004). This is because values-based complexity exposes a misalignment of organizations' narrowly focused identities relative to their complex and varied stakeholder environment. Organizational success is thus rendered equivocal, prompting actions that deviate from prior patterns of action. And because values-based complexity is often rooted in powerful yet divergent interests which scrutinize and control organizations' actions (Wry, Cobb, \& Aldrich, 2013), we expect that as such complexity increases, organizations will feel pressured to move beyond simple shifts in their communications toward more consequential shifts in their actions. Although such inconsistent action might allow these organizations to mobilize support from a broader range of stakeholders, it might also open them up to criticisms of diverting resources away from their primary business models (Walker \& Wan, 2012). In other words, not only can valuesbased complexity result in increased uncertainty about how to prioritize different value claims, but it can also instigate compromises that allow for emergent divergence between an organization's actions and its previous patterns of action. Building on these arguments, we propose the following: 


\section{Proposition 1: By exposing misalignment between the organization's identity and its audiences, values-based complexity increases the organization's propensity of inconsistent organizational action.}

In the next section, we consider the organizational contingencies that affect the relationship between values-based complexity and inconsistent organizational action, such that these actions are more or less coordinated and diverge from more or less central aspects of the organizations' business models. As we argued, values-based complexity primarily encourages inconsistent organizational action by disrupting patterns of attention and intention amongst organizations, their leaders, and their members. However, although most organizations are exposed to some degree of values-based complexity, prior theory would suggest that those organizations are unlikely to process or make sense of such complexity in the same way given differences within those organizations (Fiss \& Zajac, 2006; Thomas, Clark, \& Gioia, 1993). The organizational conditions we thus consider next—organizational mindfulness and resource discretion—represent important factors which prior scholarship has substantiated as further affecting those same socio-cognitive mechanisms of members' attention and intention (Ocasio, 2011; Pfeffer \& Salancik, 1978).

\section{How Organizational Mindfulness Moderates the Relationship between Values-Based Complexity and Inconsistent Organizational Action}

Organizations vary in how much attention they dedicate to environmental cues due to differences in processes associated with noticing, encoding, interpreting, and then acting upon cues from the environment (Ocasio, 1997, 2011). Organizational mindfulness, in particular, has been suggested to significantly shape organizing under environmental complexity by influencing members' attention (Levinthal \& Rerup, 2006; Sutcliffe, Vogus, \& Dane, 2016; Vogus \& Sutcliffe, 2012; Weick \& Sutcliffe, 2006). Organizational mindfulness specifically involves organizational processes that enable an "ongoing scrutiny of existing expectations, continuous refinement and differentiation of expectations based on newer experiences that make sense of unprecedented 
events, a more nuanced appreciation of context and ways to deal with it, and identification of new dimensions of context that improve foresight" (Weick \& Sutcliffe, 2001: 42). In this way, organizational mindfulness increases not the quantity of attention but rather the quality of the attention organizations devote to dynamic and peripheral issues facing the firm, allowing for greater comprehension of external stimuli (Levinthal \& Rerup, 2006; Weick, Sutcliffe, \& Obstfeld, 1999). Extending this argument to our context, we propose that organizational mindfulness shapes the relationship between values-based complexity and mission drift by enhancing the attentional quality organizations devote to that complexity.

Mindfulness allows organizational members to remain cognitively open to reflecting on values-based complexity rather than attempting to explain it away. This is accomplished by way of organizational policies and simulations (e.g., scenario planning) which encourage attention to peripheral or rare events (Rerup, 2009) while offering toolkits that aid in the recognition of innovative opportunities yet discourage "bandwagon" adoption of those perceived opportunities (Swanson \& Ramiller, 2004). Amidst such organizational environments, leaders are thus more likely to arrive at greater comprehension of how such values-based complexity might affect their organizations, as they move beyond reliance on existing schemas to interpret that complexity (Vogus \& Welbourne, 2003). We argue that this openness and improved leader-based comprehension of values-based complexity increases the likelihood of inconsistent action which is more highly coordinated. By 'coordination' we refer to the degree of leader-based design and oversight of tasks and activities to achieve a common outcome (March \& Simon, 1958; Miles et al., 1978).

Inconsistent, yet coordinated organizational action, we argue, stems from leaders' awareness of values-based complexity, recognition of the perceived uncertainty which 
accompanies such awareness, and motivated attempts to make relevant adjustments to the organization's activities in light of such perceived uncertainty. Such adjustments are consistent with those undertaken by entrepreneurs, as they adjust their business models and strategies to improve alignment between the skills and resources at hand and their environment (Wiltbank, Dew, Read, \& Sarasvathy, 2006) — environments which are often characterized by high degrees of uncertainty (McMullen \& Shepherd, 2006; Sarasvathy, 2001). For instance, Royal Dutch Shell has relied on rigorous scenario-based planning for the past half-century to focus its members' attention and intentions not only on probable futures but also plausible ones (Bentham, 2014). In doing so, this has allowed the organization to attend to weak cues regarding the possible evolution of cultural values and then to change in coordinated ways that ensured the organization's sustainability.

In contrast, amidst organizational environments characterized by limited organizational mindfulness, leaders may be fixated on the past and/or the future, failing to fully attend to the information being received in the present. Such limited organizational mindfulness will discourage leaders from fully attending to and remaining open to important values-based environmental cues, thereby prompting less coordinated, inconsistent action as members struggle to independently interpret and respond to those cues. For instance, in the 1990s activists revealed Nike's ethically questionable supply chain decisions, while also noting the way in which Nike's leadership was only loosely involved in coordinating those decisions. Yet as is the case with many complex systems, such uncoordinated and inconsistent actions are often amplified rather than suppressed. In Plowman and colleagues' study (2007) of a church and emergent change, they found that small decisions were repeatedly amplified (also via uncoordinated actions) until the church had radically departed from its historic patterns of action.

In summary, we theorize that although values-based complexity encourages inconsistent 
action, organizational mindfulness increases the likelihood that such action is coordinated. As such, we propose the following:

Proposition 2: By increasing the quality of the organization's attention to values-based complexity, organizational mindfulness shapes the relationship between that complexity and inconsistent organizational action, such that the coordination of those actions increases.

\section{How Resource Discretion Moderates the Relationship between Values-Based Complexity and Inconsistent Organizational Action}

Another critical factor that shapes organizations' and their members' attention and intentions in response to values-based complexity is that of resource discretion, or leaders' latitude in allocating resources. The notion of resource discretion is comprised of both the relative internal availability of resources as well as managers' degrees of freedom in converting those available resources to other uses (Mishina, Pollock, \& Porac, 2004). Prior studies suggest that at the low end of resource discretion, for instance, organizations and their leaders are more dependent upon and beholden to powerful external actors (e.g., competitors, suppliers, buyers, and regulators) for resources (Pfeffer \& Salancik, 1978). Alternatively, at the high end of resource discretion, organizations are thought to be characterized by a high degree of resource slack or the "cushion of actual or potential resources" which among other things allows an organization "to initiate changes in strategy with respect to the external environment" (Bourgeois, 1981: 30). This prior research offers insight into the ways that resource discretion might affect how organizations engage in inconsistent action by first shaping those organizations' and their members' attention and intentions.

We build on this literature to theorize how, in the context of values-based complexity, resource discretion is particularly likely to affect whether the inconsistent actions involve core versus peripheral strategic features of the organization's business model (Hannan et al., 2006; Zott \& Amit, 2009). Consistent with Hannan and Freeman's (1984: 156) arguments, we view an 
organization's core strategic features as those having to do with the "marketing strategy in a broad sense - the kinds of clients (or customers) to which the organization orients its production and the ways in which it attracts resources from the environment." In other words, we refer to the essential components of the organization's business model-e.g., its value proposition (i.e., the distinctive opportunity it is attempting to realize coupled with the solutions it enacts in response) and its primary customer segments. As Hannan and colleagues argue, such features are 'core' precisely because changes to those features "raise fundamental questions about the nature of the organization" (Hannan et al., 2006; Hannan \& Freeman, 1984: 156). Alternatively, peripheral features are those components that are supportive of but not deemed essential to the business model. These peripheral aspects would include activities that are related but not limited to supply chain composition, administration, and the tactical implementation of the overarching marketing strategy.

Lower levels of resource discretion are often coupled with an increase in the organizational environment's influence over the strategic choices of the organization (Wry et al., 2013). Such dependence of the organization on powerful external actors disrupts the presumed link between the organization's identity and its actions. The disruption is more likely when organizations face values-based complexity, where stakeholders with different interests and values tend to impose divergent and competing demands. For example, many academic institutions are beholden to the interests of regulatory agencies, accreditation groups, ranking agencies, scholarly journals, and students. While the interests of these different groups may at times overlap, in many cases they do not. In such cases, the organizations' members may shift their attention and intentions toward serving the interests of those actors, who control the highest proportion of the organization's potential resources (Aldrich \& Pfeffer, 1976; Kraatz et al., 2010). These interests are often exposed 
through the provision of feedback, whereupon potential resource providers signal their general values and specific concerns regarding an organization's business model, thereby encouraging revision to those models (Grimes, 2017). Without the internal resources or governance arrangements to buffer decision makers from the external influence of values-based complexity, we expect that those decision makers are more likely to shift their attention and intentions, engaging in inconsistent actions that affect the core aspects of their business models.

Higher levels of resource discretion allow greater strategic choice, and yet prior scholarship does not suggest that such added choice will diminish the likelihood of inconsistent action. As McGrath notes (1999: 21), “According to conventional thought, motivation to pursue highvariance opportunities" is at least in part "a function of the availability of resources." Similarly, Nohria and Gulati (1996) find evidence that the greater availability of internal organizational resources encourages less disciplined experimentation. This is because excess resource slack allows organizations to not only condone but actively encourage members to shift their attention and intentions toward "pet projects." Moreover, as such slack increases, organizations become more willing to allow for undisciplined experimentation, even when such experimentation might result in shifts in the core features of the organizations' business models. The implication is then that when organizations face values-based complexity and maintain higher levels of resource discretion, the likelihood increases that their members will engage in inconsistent organizational actions that affect the core aspects of their business models. For example, at the turn of the century, investors had bid up America Online's stock price to record highs, allowing the CEO, Steve Case, to attempt a fundamental reconfiguration of the company by acquiring Time Warner for $\$ 165$ billion (McGrath, 2015).

In contrast with both high and low levels of resource discretion, medium levels of resource 
discretion (i.e., parity between resource availability and resource requirements) allow for, and perhaps even demand, greater allegiance to core aspects of the organization's business model. Through such resource parity, medium levels of resource discretion minimize organizations' dependence on external resource providers while similarly minimizing access to discretionary funds - both of which could encourage distortions away from core features of the organization's business model. Therefore, moderate levels of resource discretion encourage firms to focus on operational frugality (e.g., maintaining slim margins) and executing core business activities with effectiveness (Wiengarten, Fan, Lo, \& Pagell, 2017). In this way, moderate levels of resource discretion condition the relationship between values-based complexity and inconsistent action by encouraging shifts to peripheral rather than core features of a business model.

Taken together, we suggest that conditional on values-based complexity, the relationship between resource discretion and the centrality of inconsistent organizational action is U-shaped. At both the lowest and highest levels of resource discretion, organizations will be more likely to engage in inconsistent action that affects the central aspects of those organizations' business models. Stated formally, we propose the following:

Proposition 3: Conditional on values-based complexity, an organization's level of resource discretion shapes the nature of inconsistent organizational action, directing such action toward core versus peripheral aspects of the organization's business model. At lower levels of resource discretion organizations become increasingly dependent on the environment for resources, such that the likelihood of core, inconsistent action increases. At medium levels of resource discretion, organizations are not dependent on the environment for resources yet do not have substantial resource slack such that the likelihood of core, inconsistent action decreases, yet peripheral, inconsistent action increases. At higher levels of resource discretion organizations become less disciplined about investments such that the likelihood of core, inconsistent action increases.

\section{INCONSISTENT ORGANIZATIONAL ACTION AND AUDIENCE EVALUATIONS OF MISSION DRIFT}

As organizations engage in inconsistent action, audiences are prone to evaluate and form judgements regarding these inconsistencies. In this study, we are particularly interested in 
theorizing the evaluations which relate to audiences' judgments of an organization's mission drift. Specifically, we argue that differences in organizations' inconsistent actions contribute to audiences' judgments by affecting perceptions of those organizations' authenticity and responsiveness. Our arguments in this regard are consistent with social actor conceptions of organizational identity, which suggest that audiences consistently monitor discrepancies between the organization's actions and two specific reference points: the organization's image (to assess authenticity) and the organization's stakeholder environment (to determine responsiveness) (King \& Whetten, 2008).

Audience perceptions of the organization's identity establish features that "represent default expectations held by audiences about organizational properties and constraints over properties" (Hsu \& Hannan, 2005: 475). These perceptions comprise the organization's image and, in a sense, serve as a "set of rules" against which the organization interacts with and is subsequently evaluated by external audiences. When an organization acts in a way that is perceived as a violation of its image (and therefore, those default expectations), external audiences will evaluate those organizations as more or less inauthentic (Harrison et al., 2009). Ibarra and Barbulescu (2010: 140) define authenticity at the individual level as "integrity of self and behavior within and across situations," and we would extend this definition to include organizations. For example, concerns of authenticity can get introduced when organizations which claim to be environmentally responsible act in ways that are counter to those claims, leading to attributions of "greenwashing." (Carlos \& Lewis, 2017; Chandler, 2014). Similarly, following the financial crisis of 2008 many organizations experienced threats to perceptions of authenticity due to a perceived incongruence between actions and stated missions. For example, many firms caught up in the crisis had clearly stated missions focused on integrity (J.P. Morgan Chase; AIG), excellence (AIG, Lehman 
Brothers) and "unwavering" commitment to customers and shareholders through trusting relationships (Lehman Brothers; Merrill Lynch). Such actions when they prompt concerns over the organization's authenticity will form the basis for audience judgements of the organization's mission drift. At the extreme, these perceptions of inauthenticity take on moral judgment, such that audiences perceive inconsistent action not merely as a violation of the organization's image but of some threshold standard of appropriate behavior (Selznick, 2000).

Audience perceptions of the organization's stakeholder environment impose another set of expectations separate from the organization's image. Environment-based expectations often correspond with regulatory, cultural, and socio-cognitive pressures which encourage organizational conformity. To the extent that an organization's actions remain consistent over time despite shifting environmental expectations, this can introduce concerns regarding the organization's responsiveness (Jay, 2013; Raffaelli \& Glynn, 2014; Schildt \& Perkmann, 2016). For instance, in 1999 Blockbuster began recognizing a shift in the consumption of media content: Netflix had recently been founded (1997), and Amazon (1994) was beginning to exploit book and DVD sales opportunities online. Responding by way of peripheral changes to their business model (e.g., partnering with AOL, TiVo, and DIRECTV), Blockbuster did not launch an online DVD rental program (to compete with Netflix) until 2004 - the same year Coinstar introduced Redbox DVD kiosks to the market (Poggi, 2010). Similarly, they did not open Redbox-like kiosks until 2008. Rather, Blockbuster recommitted to its existing business model by seeking to purchase its main rival Hollywood Video. These shifts were thus perceived as unresponsive to the changing cultural values impacting media consumption (Shih, Kaufman, \& Spinola, 2007). Consequently, inconsistent action, although likely to prompt concerns regarding the organization's authenticity, may be necessary for ensuring the organization's perceived responsiveness to its stakeholder 
environment.

In summary, we theorize that when organizations' act in ways that are inconsistent with their image, this will increase perceptions of inauthenticity and thus judgments of mission drift. However, such judgments of mission drift, we argue, also involve evaluations of the organization's responsiveness, wherein inconsistent action may be deemed necessary and even beneficial. And these perceptions of inauthenticity and responsiveness run orthogonally to one another, such that judgments of mission drift can vary independently in the degree of perceived inauthenticity and responsiveness. In this way, mission drift, although introducing possible liabilities for the organization, also poses possible benefits related to its survival.

Proposition 4a: When organizations engage in inconsistent organizational action amidst values-based complexity, this increases the degree to which external audiences will judge those actions as mission drift. These judgements are comprised of perceptions of the organization's authenticity and responsiveness.

In the following subsections, we build on the arguments above and theorize that the perceptions which comprise mission drift depend on the nature of the inconsistent action.

\section{How the Degree of Coordination involved in Inconsistent Action Affects Perceptions of Authenticity}

When audiences form judgments of mission drift, they are likely to evaluate the underpinning motives that have led to inconsistent action. Social-psychologists have argued that audiences attempt to identify and attribute causal explanations for others' behavior to feel in control of their environments (Regan, 1978). When organizations act with higher levels of coordination, for instance, this increases external audiences' attributions of intentionality on the part of the organization and its leaders (Dasborough \& Ashkanasy, 2002). As such although any actions that diverge from the ex ante organizational image might be perceived as inauthentic, the likelihood and degree to which these actions are perceived as inauthentic can be mitigated if the 
actions in question are also coupled with attributions of intentionality arising from the organizations' coordination.

Specifically, coordinated change, because it increases audiences' attributions of intentionality, has several characteristics that render it less susceptible to perceptions of inauthenticity. First, divergent actions are more likely to be perceived as an "entrepreneurial" or "strategic" extension to the organization's image rather than a careless violation when they appear to stem from intentional efforts on the parts of the organization's leaders. Second, coordinated actions, which increase attributions of intentionality, are more likely to be perceived as a rational rather than irrational deviation such that although the actions may be perceived as inconsistent with the organization's image, the organization may still be perceived as authentic in terms of its broader correspondence with what we expect from rational institutions (Meyer \& Rowan, 1977). Third, coordinated action is often coupled with public announcements which manage audience attributions of intentionality by reframing the associated deviance as "building upon" rather than “challenging" prior assumptions underpinning the organization's image. Thus, given that mission drift can vary in its degree of coordination, this variation is likely to affect the extent to which a particular set of inconsistent actions are viewed as an intentional extension to or natural evolution of the organization's image versus a violation that moves the organization away from the public's perceptions of its principles, values, and commitments. Because perceptions of authenticity are informed not only by way of the degree of consistency in actors' behaviors over time but also the degree of intentionality attributed to those behaviors, we argue that higher coordination which increases those attributions of intentionality will mitigate audiences' concerns regarding an organization's inconsistent action.

For example, when Google launched in 1998, its stated mission was to "organize the 
world's information and make it universally accessible and useful." However, despite this stated mission and the ensuing image that audiences formed of the organization, Google continuously engaged in coordinated efforts that deviated from its stated mission, pursuing new markets in fields such as robotics, artificial intelligence, health, and biotechnology. Such coordination gave audiences the impression that these additions to Google's business were intentional efforts to add to its existing identity as an information processing and search organization. As such, these deviations were consistently evaluated as rational, entrepreneurial, and committed to appropriately evolving with emerging trends to extend and improve upon its core identity. Fourteen years after its launch, Larry Page suggested that the organization had "outgrown" its mission statement. Soon thereafter, the company rebranded as Alphabet, signaling to its stakeholders its simultaneous commitment to both its "core" and "non-core" business lines (Gibbs, 2014).

Alternatively, uncoordinated and inconsistent organizational action often entails members operating on their own accord. Such decentralized action, when it is inconsistent with the organization's image, likely undermines not only attributions that the organization is acting intentionally but also that its leaders are attentive to the organization's activities (Felps, Mitchell, \& Byington, 2006; Heath \& Staudenmayer, 2000). Such deviance, when coupled with attributions of inattentiveness and a lack of intentionality, increase the likelihood that such actions will be interpreted as inauthentic. When organizations take a number of uncoordinated and divergent actions to respond to values-based complexity, it may seem like they are trying to be "something for everyone" (Carroll \& Swaminathan, 2000). Rather than viewing such inconsistent action as a natural extension of the organization's identity, audiences are more likely to view it as a problematic shift that violates the organization's image.

For example, General Motors (G.M.) has struggled recently in coordinating actions across 
its various vehicle brands in pursuing a common organizational objective, leading to changes that not only increased competition amidst its own brands but also appeared inconsistent with customer expectations for each of the brands. As an example, Chevrolet released several luxury automobiles $(\sim \$ 50,000)$, in many cases pricing them higher than the G.M.'s premium brand Cadillac. However, at the same time, some Chevrolet vehicles were marketed at the same price point $(\sim \$ 15,000)$ as Saturn, Pontiac, Buick and Oldsmobile. As business and brand managers "pushed the boundaries" of the policies governing their business units to offer greater variety to customers, G.M. ended up producing vehicles that were perceived as inauthentic to the underlying brands (Trout, 2005).

In combining the arguments above, we propose the following:

Proposition 4b: By increasing the degree to which inconsistent organizational actions are perceived as intentional extensions rather than unintentional violations of an organization's existing image, coordination of those actions will decrease audiences' perceptions of inauthentic mission drift.

\section{How the Core versus Peripheral Nature of Inconsistent Action Affects Perceptions of Responsiveness}

While the degree of coordination involved in inconsistent action likely affects audience perceptions of the organization's authenticity, we argue that the extent to which inconsistent action relates to core versus peripheral features of the organization's business model is instead most likely to affect perceptions of the organization's responsiveness - its ability to demonstrate alignment and requisite variety relative to the institutional environment. Specifically, we argue that inconsistent action which affects core features of the business model increases perceptions of responsiveness by, first, directing audience attention toward the magnitude of the challenges associated with values-based complexity in the environment. Because changes to the core features of an organization's business model such as its value proposition are also the most easily observable by external audiences, these changes often prompt third-party analysis of both the 
change and the impetus for such change. For example, although Tesla started as an automobile manufacturer and retailer, the company made dramatic shifts in its core business model toward energy storage and alternative energy production. Recently the company invested billions of dollars into the creation of the world's largest battery production factory, leading Forbes and other media outlets to comment on how Tesla is now "a battery business, not a car business" and to recognize the need for such a shift in the company's business model (Wald, 2017). As such by increasing audience awareness of organizational change and the values-based complexity which prompted it, inconsistent action targeting more central features of the organization's business model increases audiences' perceptions of the organization's responsiveness to its environment.

Second, inconsistent action of this kind increases audience perceptions of the organization's responsiveness by introducing core operational differences that highlight requisite variety amidst values-based complexity. Exposed to different and shifting stakeholder values, organizations may recognize that their current business model and resource endowment insufficiently align with those values. According to the principle of requisite variety, aligning with a changing or variable environment may require a similarly complex or complicated business model and repertoire of resources (Ashby, 1991; Weick, 1987). This principle, drawn from cybernetic theory, suggests that alignment between lower- and higher-order systems requires that the variation in the lower-order system (e.g., an organization) be commensurate with the variation in the higher-order system (e.g., the organizational environment). Although, in general, requisite variety between an organization and its environment might be achieved by way of limited or peripheral adjustments to the organization's business model, this is not the case amidst complexity (e.g., values-based complexity). As complexity theorists argue, when organizations are exposed to high degrees of environmental variation and dynamism, organizations must move far enough away 
from a state of equilibrium (which is considered a precursor to failure) toward "the edge of chaos...by disrupting existing patterns and ways of doing things" (Pascale, 1999; Plowman et al., 2007: 527). Given such insights from complexity theory, it seems that core rather than peripheral deviations from an organization's overly narrow original state would be necessary to introduce the requisite variety needed to respond to values-based complexity. Most importantly, by demonstrating requisite variety, organizations increase the likelihood that external audiences will view the organizations as highly attentive to their environments.

For instance, as the online media environment continues to fluctuate, Netflix continues to succeed in large part by disrupting its own core business model. Beyond its commitment to distributing third-party content, Netflix began reducing its dependence on content providers by developing its own original programming. In 2006, the company launched an independent content creation and distribution arm called Red Envelope, only to close it two years later. Yet the success of its streaming platform began highlighting and perhaps contributing to the values-based complexity of its consumer base. For instance, Netflix was able to aggressively track consumer trends and preferences, resulting in over 3,000 categories for classifying consumer tastes. With this deep insight of its different consumers and their divergent values, the company relaunched its content creation strategy. Such actions demonstrate a commitment to increasing the variety of its business model to ensure continued responsiveness amidst values-based complexity.

In contrast, when organizations engage in inconsistent action that affects the peripheral rather than core features of their business models, stakeholders may view these changes as inattentive and unnecessary deviations that divert already limited resources toward unrewarding pursuits instead of toward more extensive endeavors to execute the organization's original mission more efficiently (Greenwood \& Hinings, 1996; Huy, Corley, \& Kraatz, 2014). Although such 
peripheral changes may go unnoticed or ignored, to the extent that they are noticed, this form of "business model tinkering" could be viewed as an inattentive waste of resources and/or an attempt to make impulsive adjustments in response to external cues rather than a more committed effort to navigate rapidly evolving and complex values (Huy, 2002). For example, in the late 1970s, Liz Claiborne founded a company with an organizational identity centered on manufacturing more formal business attire catered to professional women. As such, the company configured various aspects of its value chain, such as design, merchandise presentation, retailer sales, marketing, and production/distribution, to align with that identity. Starting in the 1990s, however, customer values associated with business attire became more varied, and companies increasingly allowed employees to dress casually. As a result, Liz Claiborne's exclusive emphasis on more formal wear became insufficient. While these cultural shifts required a larger-scale reconfiguration of Liz Claiborne's business model to align with more varied consumer preferences, it responded with some piecemeal initiatives that ultimately led to its performance decline (Siggelkow, 2001).

Taken together, we argue that inconsistent organizational action that targets core features of the business model will increase audience perceptions of more significant, attentive organizational change and thus organizational responsiveness. These perceptions expose the accompanying environmental complexity while simultaneously highlighting the requisite variety associated with the organization's current operations amidst values-based complexity. In contrast, smaller incremental shifts will likely be interpreted as insufficiently varied and thus poorly responsive to such values-based complexity. In combining the arguments above, we propose the following:

Proposition 4c: By increasing attributions of the organization's attentiveness, actions that differ from prior organizational actions in core (vs. peripheral) ways will increase external audiences' perceptions of responsive mission drift. 


\section{MISSION WORK: HOW ORGANIZATIONS RESPOND TO AUDIENCE PERCEPTIONS OF INAUTHENTICITY AND UNRESPONSIVENESS}

Organizations engage in active attempts to manage their image, and thus changes to an organization's image often prompt both practices aimed at impression management as well as more substantive governance-related changes that result in lasting organizational change. For instance, Dutton and Dukerich (1991) in their study of the Port Authority of New York show how this organization's early responses to the issue of homelessness involved impression management, yet as the organization's image continued to deteriorate, the organization subsequently began to introduce new policies and partnerships aimed at better responding to the issue and repairing its image. In the case of mission drift, the potential damage to the organization's image is foundational, as audiences question the relationship between the organization's actions and its identity. In this case, we argue, organizations are likely to engage in 'mission work' - efforts to repair the connection between an organization's image and its action. Although mission work operates within organizations and focuses on the maintenance of the organizations' identities and images, the concept is similar to that of institutional work, in that they both focus on actors purposive action toward the development and reparation of socio-cognitive prescriptions (Lawrence \& Suddaby, 2006). To effectively accomplish such reparation, mission work specifically seeks to demonstrate past or current attentiveness to values-based complexity as well as strategic intentionality, and in so doing improve audience perceptions of the organization's authenticity and responsiveness.

In this section, we theorize a number of practices that seek to overcome external perceptions of an organization's inauthenticity and unresponsiveness. Specifically, we identify a number of both impression management and governance-related practices designed to resolve emergent ambiguity regarding the organization's attentiveness and strategic intentions. The 
practices we denote below are not meant to be an exhaustive list of the options available for organizations wishing to engage in mission work; rather, they are meant to highlight exemplary practices drawn from existing theory. Building on prior scholarship (Dutton \& Dukerich, 1991), we argue that there is a sequential relationship between these practices, such that organizations are first prone to engage in impression management in response to perceived mission drift. Such impression management practices take the form of sensegiving, attempting to influence the "meaning construction of others toward a preferred redefinition of ... reality" (Gioia \& Chittipeddi, 1991: 442). In the case that those practices fail to effectively repair the perceived relationship between those organizations' actions and their images, organizations will then engage in more substantive governance-related actions to do so.

\section{Mission Work to Overcome Perceptions of Inauthenticity}

We argue that a number of impression management practices can be deployed to highlight the strategic intentions underpinning prior inconsistent organizational actions, while a set of governance-related practices can be used to demonstrate tighter coupling between its current actions and its identity. Such mission work helps address perceptions of inauthenticity associated with inconsistent organizational actions.

Impression management practices. Prior scholarship has identified three different impression management practices, which are likely useful as means for increasing audience perceptions of the organization's authenticity despite the presence of inconsistent action. One such practice is that of containing (Dutton \& Dukerich, 1991). The focus here is on containing the reputational damage associated with judgments of mission drift. At first, organizations may try to contain judgements of mission drift by minimizing public awareness and scrutiny of the associated inconsistent actions. In cases wherein public awareness of the details of those actions are well- 
known, however, organizations may then try to downplay the significance of those actions. In both of these cases, organizations seek to increase attributions of intentionality, by revealing that inconsistencies in their action were minor or unremarkable deviations. For example, in 2012 Google acquired Motorola Mobility for $\$ 12.5$ billion. This purchase led to speculation that Google was interested in developing its own devices to compete with other major players, such as Apple. However, in 2014 Google sold most of Motorola Mobility to Lenovo for \$2.91 billion. To explain these actions, Google emphasized that the purchase was primarily for patents to defend Android against lawsuits. They downplayed the notion that such actions might entail mission drift and rather touted the value they received out of the deal given the acquired patents.

Conversely, another impression management practice related to mission work is that of justifying, whereby organizations attempt to dismiss concerns regarding inauthenticity by claiming strategic intent and offering arguments to justify the connection between the inconsistent actions and the organization's prior actions. Whereas containment seeks to conceal the inconsistent actions, justifying seeks to reveal and defend those actions. The imperative in this case is to clearly demonstrate how those actions fit within the scope of the existing mission statement of the organization. For instance, Sonenshein's (2010: 486) case study of a Fortune 500 retailer demonstrates how the company's launch of a new retail arm was followed by communications, which attempted to balance claims of novelty with claims of familiarity. An email sent to both employees and customers noted, "We're unveiling a new look for a familiar friend."

Organizations might also engage in the impression management practice of abstracting, whereby they broaden their identity claims to accommodate both old and new strategies simultaneously. This process could be as simple as an organization extending its mission and selfcategorization beyond its prior associations with an original product or market: for instance, a 
phone maker relabeling itself as a "technology company" or a strategy consulting firm relabeling itself as a "business solutions company." As firms engage in abstracting, they can reiterate the validity of their original identity, mission, and strategies while simultaneously expanding on and validating new and evolving components of each. Tesla's recent name change from "Tesla Motors, Inc." to "Tesla, Inc." exemplifies abstraction mission work. The name change reflects Tesla's expanding investments and strategies into energy storage and production, which deviated beyond the company's mission at the time. Other similar examples include Apple's name change from “Apple Computer, Inc.” to “Apple Inc.” and Google’s creation of "Alphabet Inc.”, following these companies' investments in opportunities beyond the scope of their original missions.

Taken together, each of these three practices increase communications between organizations and their audiences in ways that attempt to influence attributions of intentionality, thereby minimizing any emergent concerns regarding the organization's authenticity. Accordingly, we propose the following:

Proposition 5a: Organizations will initially respond to audience perceptions of inauthenticity by way of impression management practices (e.g., containing, justifying, abstracting) aimed at influencing attributions of those organizations' intentionality. Such attributions will improve audience perceptions of the organization's authenticity.

Governance-related practices. When impression management fails to repair the perceived link between an organization's actions and its image, the organization will then pursue more aggressive efforts to reconfigure its strategic governance. Given that judgments of mission drift arise in part because of inconsistent action, mission work focused on strategic governance involves attempts to improve the coordinating function of the organization to demonstrate strides toward high consistency. Here, prior studies of high-reliability organizations (HROs) provide a basis for understanding how organizations might structure their actions to ensure greater continuity between those actions and their organization's identity and image. While HRO research primarily 
focuses on organizations specifically tasked with managing or preventing crises (e.g., Firefighters, Emergency Medical teams, Air Traffic controllers, Nuclear Plan workers, etc.), we anticipate that the logic holds for organizations, more generally, as they engage in mission work (Vogus, Rothman, Sutcliffe, \& Weick, 2014; Williams, Gruber, Sutcliffe, Shepherd, \& Zhao, 2017). As is the case with HROs, the challenge for organizations seeking to reliably manage values-based complexity is controlling unwanted variance.

To ensure consistent actions amidst complexity, many organizations introduce more control systems focused on the integration or tight coupling of their actions by way of greater hierarchy, tighter coordination, and closer grouping (Bigley \& Roberts, 2001). For example, in response to the aforementioned ethical concerns regarding Nike's uncoordinated supply chain decisions, the company instituted a series of governance-related changes which included the release of publicly available "Code of Conduct" and "Code Leadership Standards", which together specify the standards demanded of supply chain partners and how decision makers across the organization should implement those standards. In addition, the company now tracks and makes publicly available details regarding its supply chain partners including the percentage employment of women and migrant workers.

Consistent with the practice of integration, organizations might also introduce simple policies and routines to govern resource allocations and decision making (Bingham, Eisenhardt, \& Furr, 2007; Brown \& Eisenhardt, 1997). Simple rules have been shown to enhance performance in a dynamic environment (Rindova \& Kotha, 2001) as they allow for internal cohesion of decision-making (i.e., coordination) that can then be communicated or understood by external audiences. Furthermore, as firms continue to receive feedback regarding audience perceptions, simple rules allow for flexibility and efficiency in enacting changes (Brown \& Eisenhardt, 1997), 
providing clearer signals of the organizations intentions. In this way, the integration of organizational activities would highlight greater intentionality and strides toward consistency, demonstrating to external audiences a commitment to eliminate future inconsistency.

Conversely, some organizations might pursue the opposite approach, segregation, such that activities which might be viewed as inconsistent are embraced but separated from those activities deemed core to the business. For example, as previously noted the Walt Disney Company faced potential concerns regarding its authenticity when it considered releasing content directed at mature audiences. Disney thus announced "that it will keep some of its new movies as far away from the Disney name as possible," replacing the Disney name on those movies with that of Touchstone Films (Harmetz, 1984). To this day, the company has opted to keep these brands entirely separated to avoid perceptions of inauthenticity.

As with the aforementioned impression management practices, these practices of integration and segregation are similarly designed to convey, but in this case also ensure, consistency in the organizations' core activities, demonstrate the intentionality behind the organization's actions, and resolve any lingering concerns about the organization's authenticity. As such, we propose:

Proposition 5b: Following unsuccessful attempts at impression management, organizations will subsequently respond to audience perceptions of inauthenticity by way of governance-related change (e.g., integration and segregation) aimed at influencing attributions of those organizations' intentionality. Such attributions will improve audience perceptions of the organization's authenticity.

\section{Mission work to Enhance Perceptions of Responsiveness}

Impression Management. Perceptions of an organization's unresponsiveness call into question the extent to which the organization, its leaders, and members have been attentive to values-based complexity. As such, organizations will likely initially respond to such perceptions 
by way of impression management practices aimed at bolstering attributions of attentiveness. Notably, many organizations engage in the practice of decoupling, or the adoption of visible structures that show attentiveness to different stakeholder groups and values, while effectively buffering the core activities of those organizations, which may be deemed less attentive to those groups (Elsbach \& Sutton, 1992; Meyer \& Rowan, 1977). Such decoupling is often joined by communications which attempt to highlight the significance of minor changes in the organization's business model or occasionally even downplay the significance of any values-based complexity. For instance, large oil and gas companies often disproportionately market their alternative energy investments despite the peripheral role such investments play in their organizations. Additionally, these organizations have funded research that attempts to problematize the growing consensus that the fossil fuel industry contributes to climate change (Martyn, 2016).

In addition to decoupling, organizations can also engage in rhetorical efforts to contextualize their prior actions, attributing attentive alignment between those actions and the surrounding values-based complexity despite perceptions to the contrary. This may include efforts to improve the perceived merit of a given set of actions or outcomes or even claiming credit for a desirable outcome. For instance, in their study of Earth First! and the AIDS Coalition to Unleash Power (ACT UP), Elsbach \& Sutton (1992) examined how these organizations were able to influence audiences' attributions of the organization's responsiveness to social values despite having engaged in actions that had been labeled as "radical" and "terrorism." Specifically, these organizations influenced the public's evaluations by emphasizing the progress toward socially desirable goals despite their inappropriate actions.

Taken together, both of these practices increase communications between organizations and their audiences in ways that attempt to influence attributions of attentiveness to the divergent 
values which confront the organization, thereby minimizing any emergent concerns regarding the organization's responsiveness. Accordingly, we propose the following:

Proposition 5c: Organizations will initially respond to audience perceptions of unresponsiveness by way of impression management practices (e.g., decoupling and contextualization) aimed at influencing attributions of those organizations' attentiveness. Such attributions will improve audience perceptions of the organization's responsiveness.

Governance-related practices. Beyond such impression management practices, organizations may subsequently respond to perceptions of drift by introducing substantive changes to its strategic governance which further demonstrate its attentiveness to values-based complexity. As noted earlier, perceptions of responsiveness amidst values-based complexity are linked to an organization's ability to demonstrate requisite variety. As such, governance-related change will likely involve efforts to increase variety to map with values-based complexity. First, organizations may engage in decentralization of decision-making authority to demonstrate requisite variety amidst complexity. This could include enhanced discretion for geographically dispersed business units or separating core businesses (e.g., primary products/services) from peripheral, exploratory projects. As previously noted, Liz Claiborne suffered declining performance following its unresponsive and minor adjustments to its business model. In response, however, the company acquired nearly 30 different brands and subsequently decentralized its hierarchical structure to allow for autonomy amidst those diverse brands. In doing so, the company increased its requisite variety and thus ultimately improved perceptions of its responsiveness (Kapner, 2009).

Second, organizations can engage in diversification both with regard to its members as well as its corporate boards. To the extent that an organization is perceived as unresponsive to the values-based complexity inside the organization, it will likely respond by introducing policies to increase member diversity. Similarly, to the extent that the organization is perceived as unresponsive to values-based complexity in its environment, organizations will likely increase the 
diversity of its board, given the importance that such boards play in demonstrating alignment between the organization and its environment (Pfeffer, 1973; Siliciano, 1996). For example, in 2015 Twitter faced criticism regarding its lack of demographic diversity and thus its unresponsiveness to the diversity reflected in its user base. The company reacted by systematically adding new members to its board of directors, thereby improving audiences' view of its responsiveness (Guynn, 2016).

Both of these governance-related practices should increase audience's attributions of the respective organizations' attention to values-based complexity. As such, we propose:

Proposition 5d: Following unsuccessful attempts at impression management, organizations will subsequently respond to audience perceptions of unresponsiveness by way of governance-related change (e.g., decentralization and diversification) aimed at influencing attributions of those organizations' attentiveness. Such attributions will improve audience perceptions of the organization's responsiveness.

\section{DISCUSSION}

\section{Toward a Theory of Mission Drift}

As scholars and practitioners increasingly reference the notion of mission drift, there is still a great deal of ambiguity and inconsistency surrounding how mission drift is conceptualized and used. In this paper, we take a first step in grounding this concept theoretically. Specifically, we define mission drift as a socio-cognitive and perceptual construct. Our theory and model then offer insight into how such perceived drift can vary, explaining the factors and conditions that give rise to such variation and describing how organizations then account for and respond to mission drift. Taken together, we provide new insight that relates mission drift to the ostensibly contradictory demands that organizations experience for both internal stability and external adaptability (March, 1991; Thompson, 1967). Our paper aims to make three primary contributions to our understanding of mission drift as it relates to existing scholarship on organizational identity, organizational 
adaptation, and the evolution of purpose-driven organizations.

\section{The Socio-cognitive Implications of Mission Drift for Organizations}

The topic of mission drift is important not only because it introduces questions about the overlap between organizational actions, identities, and images but also because such overlap or the lack thereof has implications for how audiences evaluate those organizations. In examining mission drift as a perceptual construct underpinned by audience evaluations, we noted the presence of a theoretical tension. On the one hand, mission drift might be understood as a form of adaptive response to the environment (Dutton \& Dukerich, 1991). However, on the other hand, the associated actions could be perceived as a violation of the organization's image, undermining fundamental audience expectations about those organizations (Harrison et al., 2009).

Our theory and model help resolve this tension by describing different types of mission drift. Specifically, we highlight how inconsistent action gives rise to different perceptions of mission drift_-perceptions, which are based on the degree to which audiences deem organizations' actions as inauthentic and responsive. We also highlight that organizations are not merely recipients of such judgments but instead actively work to address them through mission work. When organizations effectively engage in mission work that appropriately addresses the liabilities associated with each type of drift, this effort should positively reshape the relationship between inconsistent action and perceptions of mission drift. In this way, our theory and model establish that the relationship between mission drift and audiences' evaluation is contingent on not only the type of inconsistent action undertaken but also organizations' capacity to skillfully respond to external evaluations of such action.

In highlighting the potential for both positive and negative perceptions associated with drift, we challenge existing research that has exclusively regarded the phenomenon as a pernicious 
organizational outcome resulting from organizational mismanagement (Battilana \& Lee, 2014; Yunus, 2011). We believe our study highlights future opportunities to expand on the potential tradeoffs associated with mission drift. For example, future research could explore the role of mission drift at different stages of the organizational lifecycle. Given the heightened need for adaptation, might drift be more positive when organizations are emerging?

Also, our conceptual study focused largely on external audiences' evaluations of authenticity and responsiveness as a basis for understanding perceptions of an organization's mission drift. Internal to the organization, however, organizational members are prone to evaluate not only their own organization's actions but also the evolving external image of their organization. Indeed, as we argue and others have shown, concerns over their organization's image can prompt members and leaders to take action to repair any perceived damage to the image (Dutton \& Dukerich, 1991). Yet this raises additional questions as well. What happens if the employees of an organization detect mission drift prior to external audiences? Future scholarship might, for instance, consider how this could affect members' identification with their organization (Besharov, 2014) or prompt whistle-blowing (Dutton, Ashford, O’Neill, \& Lawrence, 2001).

Finally, our current model attends primarily to behavioral moderators (e.g., organizational mindfulness) which shape the impacts of values-based complexity on organizations' inconsistent actions. Future scholarship on mission drift, however, would likely benefit from greater attention to the structural determinants and corporate governance configurations, which facilitate organizational mindfulness as it pertains to an organization's identity or which ensure appropriate levels of resource discretion and accountability. For instance, much has been written about the ways in which mechanistic (versus organic) organizational structures — characterized by centralized controls — encourage tight coupling 
between strategies and action (Lawrence \& Lorsch, 1967; Mintzberg \& Waters, 1985; Slevin \& Covin, 1997). Future research might thus theorize and test whether such structures also minimize the likelihood of mission drift within the organization. Yet again, since mission drift might prove beneficial at times, a more nuanced future research agenda could attend to the governance arrangements which allow for more authentic and responsive forms of mission drift, while controlling against the risk of more deleterious forms of drift.

\section{Challenging the Link between Organizational Identity and Organizational Action}

The very idea of mission drift has been viewed as theoretically provocative given its implications for both strategy and organizational change. It suggests that organizations can shift in potentially insidious ways that expose fundamental discontinuities between perceptions of the central and distinctive attributes of the organization and its actions. Although prior studies have revealed the possibility of emergent discontinuities between action and organizational identity (Harrison et al., 2009; Kraatz et al., 2010), the longstanding theoretical assumption has been that identity and action are tightly coupled (Albert \& Whetten, 1985; Gioia et al., 2010) even though identity itself may evolve and adapt (Gioia et al., 2000). Organizational action, in other words, is thought to proceed directly from the organization's conceptions of its central and distinctive attributes (Glynn \& Abzug, 2002). We have argued in this paper, however, that evidence suggests otherwise - that identities often can be changed to accommodate divergent actions and not necessarily the other way around.

Mission, we have argued, provides a symbolic bridge between an organization's identity and its actions by specifying why the organization should exist and how it should act (i.e., purpose), thereby focusing members' attention and intentions, such that actions proceed from identity. When this bridge is challenged by way of values-based complexity, our arguments suggest that 
inconsistent action can ensue, leading to different perceptions of mission drift and different associated mission work aimed at overcoming those perceptions. Although some mission work (e.g., integration) attempts to rein in divergent action, other work (e.g., abstracting) involves efforts to symbolically and materially demonstrate connections between identity and action, influencing audiences' perceptions of what is thought to be central and distinctive.

By arguing that organizations can reconfigure their identities and images to realign with already divergent action, our theorizing challenges the existing understanding of the process of organizational identity change. Prior studies have argued that organizational identities evolve in deliberate and planned ways (Gioia et al., 2013) such that the "entity constructs an envisioned end state, takes action to reach it, and monitors the progress" (Van de Ven \& Poole, 1995: 516). This type of identity change is purposeful in that it adjusts conceptions of what is most central and distinctive about the organization to drive consistent action that might ultimately lead to a desired future image (Gioia \& Thomas, 1996). Thus, even inasmuch as prior research has depicted organizational identity as "relatively fluid," allowing for adaptive shifts (Gioia et al., 2000: 63), those shifts are often depicted as the product of deliberation. Our theoretical model, however, suggests that organizational identity change might also proceed in a less deliberate fashion, with the need for such change only being recognized post hoc once inconsistent action has already been taken and external audiences have evaluated such action. Specifically, our arguments draw attention to the important role that values-based complexity plays, providing the basis for emergent rather than deliberate organizational identity change by triggering instances of mission drift and forcing organizations to reconcile their identities, images, and actions.

Although we continue to see room for future scholarship that would offer further insight into how organizational identity serves as a powerful determinant of organizational action, our 
study also suggests the need for greater awareness of the dysfunctions and opportunities that might arise when actions become decoupled from the values-laden aspects characterizing organizations' identities. Future empirical research, for instance, might look to create a measure of mission drift by capturing the degree to which organizational actions diverge from organizations' publicized mission statements. Recent developments in management scholarship offer a number of tools such as content analysis (Duriau, Reger, \& Pfarrer, 2007; Short \& Palmer, 2008), web scraping (Gehman \& Grimes, 2017), and mixed methods (Williams \& Shepherd, 2016a), which might allow scholars to capture such divergence. Given the increased publicity and accessibility of mission statements on company websites, we anticipate ample opportunities to systematically document divergence between organizations' claims about themselves and their actions as well as audience reactions and organizational responses to such divergence. Similarly, scholars might document shifts in an organization's mission statements over time, testing the propositions in this study by examining the conditions under which these shifts precede or proceed from a change in organizational action. Also, as our study suggests that such mission work improves external perceptions of authenticity and responsiveness, future research might further examine the varieties and efficacy of mission work under particular conditions.

\section{Mission Drift and the Evolution of Values-Driven Enterprises}

Many organizations operate with a sense of purpose that extends beyond the pursuit of commercial ends (Grimes, Gehman, \& Cao, 2018; Miller, Grimes, McMullen, \& Vogus, 2012; Williams \& Shepherd, 2016b, 2018). Organizations, in this sense, are "infused with value," and these values may be viewed as both worthwhile ends in and of themselves and also as bases for increasing members' engagement and commitment (Selznick, 1957: 17). The notion of mission drift, however, draws attention not only to the importance of these values but also to the potential 
precariousness of such values amidst environmental complexity. In other words, there is a practical tension between an organization's efforts to preserve the values that are viewed as characteristic of or even essential to the organization itself and the organization's efforts to "fit" with the environment in cases of values-based complexity (Kraatz \& Flores, 2015; Selznick, 1992).

To date, the few studies that have explicitly referenced the concept of mission drift have done so in the context of studying social enterprises, focusing exclusively on the threat it poses to the integrity of organizations' values. Our study similarly recognizes this potential but also suggests that a fuller understanding of mission drift must account as well for how, in some cases, mission drift might serve as an effective response to values-based complexity in the organization's environment. In doing so, our arguments shift attention away from merely viewing organizations as governance mechanisms for protecting or controlling organizational values toward viewing them instead as equilibrating mechanisms that help coordinate the value claims of many different stakeholders (Venkataraman, 2002). To the extent that organizations' existing values are maladapted to their current environment, we should expect evolution-sometimes in purposeful and deliberate ways (Gioia et al., 2000) and sometimes, as our study suggests, in more emergent ways.

That said, we are clearly not arguing that mission drift is a panacea, and we most certainly are not advocating that organizations should strive to drift. Organizational authenticity is critical, and this is likely even more so the case within organizations in which values are highly salient and even public (Cao, Gehman, \& Grimes, 2017; Harrison et al., 2009). Moreover, it is clear that as an organization attempts to appease all stakeholders, this may encourage compromises in its capacity to create value specifically for its most salient or centrally important stakeholder groups, which may happen to be less powerful. This scenario, of course, is consistent with the classic case of 
mission drift invoked by Muhammad Yunus (2011) and others (Armendáriz \& Szafarz, 2009), as they have expressed concern regarding microfinance organizations' ability to serve the needs of those living in poverty. In other words, as our study depicts, there are clearly examples of mission drift that are neither authentic to the organization's values nor responsive to the values reflected in the organization's environment. Therefore, although we have shown how mission drift, when combined with effective mission work, may sometimes have positive effects on audiences' evaluations of the associated organizations, it remains unclear whether such outcomes would also ultimately translate into positive effects for society. We expect and hope that future research on the topic of mission drift will prioritize such questions. Under which conditions, for example, might mission drift benefit the organization but fail society and vice versa? And under which conditions, can mission drift lead to optimal outcomes for the organization and society? 


\section{REFERENCES}

Albert, S., \& Whetten, D. A. 1985. Organizational identity. In L. L. Cummings \& B. M. Staw (Eds.), Research in organizational behavior, vol. 7: 263-295. Greenwich, CT: JAI Press.

Aldrich, H. E., \& Pfeffer, J. 1976. Environments of Organizations. Annual Review of Sociology, 2(1): 79-105.

Anderson, P. 1999. Complexity theory and organization science. Organization Science, 10(3): $216-232$.

Armendáriz, B., \& Szafarz, A. 2009. Microfinance mission drift? Research Institute in Management Sciences. https://www.microfinancegateway.org/sites/default/files/mfg-enpaper-microfinance-mission-drift-apr-2009_0.pdf.

Ashby, W. R. 1991. Requisite variety and its implications for the control of complex systems. Facets of Systems Science: 405-417. New York, NY: Springer.

Bakker, R. M., \& Shepherd, D. A. 2017. Pull the plug or take the plunge: Multiple opportunities and the speed of venturing decisions in the Australian mining industry. Academy of Management Journal, 60(1): 130-155.

Bart, C. K., \& Baetz, M. C. 1998. The Relationship Between Mission Statements and Firm Performance: An Exploratory Study. Journal of Management Studies, 35(6): 823-853.

Bartkus, B. R., \& Glassman, M. 2008. Do Firms Practice What They Preach? The Relationship Between Mission Statements and Stakeholder Management. Journal of Business Ethics, 83(2): 207-216.

Battilana, J., \& Dorado, S. 2010. Building sustainable hybrid organizations: The case of commercial microfinance organizations. Academy of Management Journal, 53(6): $1419-1440$. 
Battilana, J., \& Lee, M. 2014. Advancing Research on Hybrid Organizing -. The Academy of Management Annals, 8(1): 397-441.

Bennett, R., \& Savani, S. 2011. Surviving mission drift: How charities can turn dependence on government contract funding to their own advantage. Nonprofit Management and Leadership, 22(2): 217-231.

Bentham, J. 2014. The scenario approach to possible futures for oil and natural gas. Energy Policy, 64: 87-92.

Besharov, M. 2014. The Relational Ecology of Identification: How Organizational Identification Emerges When Individuals Hold Divergent Values. Academy of Management Journal, 57(5): 1485-1512.

Bigley, G. A., \& Roberts, K. H. 2001. The Incident Command System: High-Reliability Organizing for Complex and Volatile Task Environments. The Academy of Management Journal, 44(6): 1281-1299.

Bingham, C. B., Eisenhardt, K. M., \& Furr, N. R. 2007. What makes a process a capability? Heuristics, strategy, and effective capture of opportunities. Strategic Entrepreneurship Journal, 1(1-2): 27-47.

Blair-Loy, M., Wharton, A. S., \& Goodstein, J. 2011. Exploring the Relationship between Mission Statements and Work-Life Practices in Organizations. Organization Studies, 32(3): 427-450.

Bosse, D. A., Phillips, R. A., \& Harrison, J. S. 2009. Stakeholders, reciprocity, and firm performance. Strategic Management Journal, 30(4): 447-456.

Bourgeois, L. J. 1981. On the Measurement of Organizational Slack. The Academy of Management Review, 6(1): 29. 
Bourgeois, L. J., \& Eisenhardt, K. M. 1988. Strategic decision processes in high velocity environments: Four cases in the microcomputer industry. Management Science, 34(7): $816-835$.

Bristol-Myers Squipp Company. 2017. Mission, Vision \& Values of Bristol-Myers Squibb Company. https://www.bms.com/about-us/our-company/our-mission.html.

Brown, A. D., \& Starkey, K. 2000. Organizational Identity and Learning: A Psychodynamic Perspective. The Academy of Management Review, 25(1): 102-120.

Brown, S. L., \& Eisenhardt, K. M. 1997. The art of continuous change: Linking complexity theory and time-paced evolution in relentlessly shifting organizations. Administrative Science Quarterly, 42(1): 1-34.

Cao, K., Gehman, J., \& Grimes, M. G. 2017. Standing out and fitting in: Charting the emergence of Certified B Corporations by industry and region. In A. C. Corbett \& J. A. Katz (Eds.), Hybrid Ventures, vol. 19: 1-38. Emerald Publishing Limited.

Carlos, W. C., \& Lewis, B. W. 2017. Strategic Silence: Withholding Certification Status as a Hypocrisy Avoidance Tactic. Administrative Science Quarterly, 63(1): 130-169.

Carroll, G. R., \& Swaminathan, A. 2000. Why the Microbrewery Movement? Organizational Dynamics of Resource Partitioning in the US Brewing Industry 1. American Journal of Sociology, 106(3): 715-762.

Chandler, D. 2014. Morals, Markets, and Values-Based Businesses. Academy of Management Review, 39(3): 396-406.

Chaykowski, K. 2017, June. Mark Zuckerberg Gives Facebook A New Mission. https://www.forbes.com/sites/kathleenchaykowski/2017/06/22/mark-zuckerberg-givesfacebook-a-new-mission/\#5ae1c2461343. 


\section{Citigroup. 2017. About | Citi - A Mission of Enabling Growth and Progress. http://www.citigroup.com/citi/about/mission-and-value-proposition.html.}

Corley, K. G., \& Gioia, D. A. 2004. Identity ambiguity and change in the wake of a corporate spin-off. Administrative Science Quarterly, 49(2): 173-208.

Crotts, J. C., Dickson, D. R., \& Ford, R. C. 2005. Aligning organizational processes with mission: The case of service excellence. The Academy of Management Executive, 19(3): 54-68.

Dance, G. J. X., Confessore, N., \& LaForgia, M. 2018, June 3. Facebook Gave Device Makers Deep Access to Data on Users and Friends. The New York Times.

Dasborough, M. T., \& Ashkanasy, N. M. 2002. Emotion and attribution of intentionality in leader-member relationships. The Leadership Quarterly, 13(5): 615-634.

Davis, J. P., Eisenhardt, K. M., \& Bingham, C. B. 2009. Optimal structure, market dynamism, and the strategy of simple rules. Administrative Science Quarterly, 54(3): 413-452.

De Luque, M. S., Washburn, N. T., Waldman, D. A., \& House, R. J. 2008. Unrequited profit: How stakeholder and economic values relate to subordinates' perceptions of leadership and firm performance. Administrative Science Quarterly, 53(4): 626-654.

Domanski, H. 2018, April. Facebook's new ad campaign admits the social network has lost its way. TechRadar. https://www.techradar.com/news/facebooks-new-ad-campaign-admitsthe-social-network-has-lost-its-way.

Duriau, V. J., Reger, R. K., \& Pfarrer, M. D. 2007. A content analysis of the content analysis literature in organization studies: Research themes, data sources, and methodological refinements. Organizational Research Methods, 10(1): 5-34. 
Dutton, J. E., Ashford, S. J., O’Neill, R. M., \& Lawrence, K. A. 2001. Moves That Matter: Issue Selling and Organizational Change. Academy of Management Journal, 44(4): 716-736.

Dutton, J. E., \& Dukerich, J. M. 1991. Keeping an eye on the mirror: Image and identity in organizational adaptation. Academy of Management Journal, 34(3): 517-554.

Dutton, J. E., \& Penner, W. J. 1993. The importance of organizational identity for strategic agenda building. Strategic Thinking: Leadership and the Management of Change, 89113.

Dyck, B. 1997. Understanding configuration and transformation through a multiple rationalities approach. Journal of Management Studies, 34(5): 793-823.

Eisenhardt, K. M., \& Martin, J. A. 2000. Dynamic capabilities: what are they? Strategic Management Journal, 21(10-11): 1105-1121.

Eller, C. 2003, June 20. Disney Comes of Age With PG-13 Rating for "Pirates.” Los Angeles Times.

Elsbach, K. D., \& Sutton, R. I. 1992. Acquiring Organizational Legitimacy through Illegitimate Actions: A Marriage of Institutional and Impression Management Theories. The Academy of Management Journal, 35(4): 699-738.

Felps, W., Mitchell, T. R., \& Byington, E. 2006. How, when, and why bad apples spoil the barrel: Negative group members and dysfunctional groups. Research in Organizational Behavior, 27: 175-222.

Fiss, P. C., \& Zajac, E. J. 2006. The Symbolic Management of Strategic Change: Sensegiving Via Framing and Decoupling. Academy of Management Journal, 49(6): 1173-1193. 
Friedland, R., \& Alford, R. R. 1991. Bringing society back in: Symbols, practices, and institutional contradictions. In W. W. Powell \& P. J. Dimaggio (Eds.), The new institutionalism in organizational analysis: 232-263.

Gehman, J., \& Grimes, M. 2017. Hidden Badge of Honor: How Contextual Distinctiveness Affects Category Promotion Among Certified B Corporations. Academy of Management Journal, 60(6): 2294-2320.

Gehman, J., Treviño, L. K., \& Garud, R. 2013. Values Work: A Process Study of the Emergence and Performance of Organizational Values Practices. Academy of Management Journal, 56(1): 84-112.

Gibbs, S. 2014, November 3. Google has “outgrown” its 14-year old mission statement, says Larry Page. The Guardian.

Gioia, D. A., \& Chittipeddi, K. 1991. Sensemaking and sensegiving in strategic change initiation. Strategic Management Journal, 12(6): 433-448.

Gioia, D. A., Patvardhan, S. D., Hamilton, A. L., \& Corley, K. G. 2013. Organizational identity formation and change. The Academy of Management Annals, 7(1): 123-193.

Gioia, D. A., Price, K. N., Hamilton, A. L., \& Thomas, J. B. 2010. Forging an identity: An insider-outsider study of processes involved in the formation of organizational identity. Administrative Science Quarterly, 55(1): 1-46.

Gioia, D. A., Schultz, M., \& Corley, K. G. 2000. Organizational Identity, Image, and Adaptive Instability. The Academy of Management Review, 25(1): 63-81.

Gioia, D. A., \& Thomas, J. B. 1996. Identity, Image, and Issue Interpretation: Sensemaking During Strategic Change in Academia. Administrative Science Quarterly, 41(3): 370403. 
Glynn, M. A., \& Abzug, R. 2002. Institutionalizing Identity: Symbolic Isomorphism and Organizational Names. The Academy of Management Journal, 45(1): 267-280.

Greenwood, R., \& Hinings, C. R. 1996. Understanding Radical Organizational Change: Bringing together the Old and the New Institutionalism. The Academy of Management Review, 21(4): 1022-1054.

Greenwood, R., Raynard, M., Kodeih, F., Micelotta, E. R., \& Lounsbury, M. 2011. Institutional Complexity and Organizational Responses. The Academy of Management Annals, 5(1): $317-371$.

Grimes, M. G. 2018. The Pivot: How Founders Respond to Feedback through Idea and Identity Work. Academy of Management Journal, 61(5).

Grimes, M. G., Gehman, J., \& Cao, K. 2018. Positively deviant: Identity work through B Corporation certification. Journal of Business Venturing, 33(2): 130-148.

Guynn, J. 2016, May 16. Twitter boosts board diversity with BET CEO. USA TODAY. https://www.usatoday.com/story/tech/news/2016/05/16/twitter-board-debra-lee-betnetworks-diversity/84458354/.

Hambrick, D. C., \& Finkelstein, S. 1987. Managerial discretion: A bridge between polar views of organizational outcomes. Research in Organizational Behavior.

Hamel, G., \& Prahalad, C. K. 2005. Strategic Intent. Harvard Business Review, 83(7/8): 148161.

Hannan, M. T., Baron, J. N., Hsu, G., \& Koçak, Ö. 2006. Organizational identities and the hazard of change. Industrial and Corporate Change, 15(5): 755-784.

Hannan, M. T., \& Freeman, J. 1984. Structural Inertia and Organizational Change. American Sociological Review, 49(2): 149-164. 
Harmetz, A. 1984, February 16. Touchstone Label to Replace Disney Name on Some Films. The New York Times.

Harrison, S. H., Ashforth, B. E., \& Corley, K. G. 2009. Organizational sacralization and sacrilege. Research in Organizational Behavior, 29: 225-254.

Heath, C., \& Staudenmayer, N. 2000. Coordination neglect: How lay theories of organizing complicate coordination in organizations. Research in Organizational Behavior, 22: 153-191.

Hollensbe, E., Wookey, C., Hickey, L., George, G., \& Nichols, C. V. 2014. Organizations with Purpose. Academy of Management Journal, 57(5): 1227-1234.

Hsu, G., \& Hannan, M. T. 2005. Identities, genres, and organizational forms. Organization Science, 16(5): 474.

Huy, Q. N. 2002. Emotional Balancing of Organizational Continuity and Radical Change: The Contribution of Middle Managers. Administrative Science Quarterly, 47(1): 31-69.

Huy, Q. N., Corley, K. G., \& Kraatz, M. S. 2014. From Support to Mutiny: Shifting Legitimacy Judgments and Emotional Reactions Impacting the Implementation of Radical Change. Academy of Management Journal, 57(6): 1650-1680.

Ibarra, H., \& Barbulescu, R. 2010. Identity As Narrative: Prevalence, Effectiveness, and Consequences of Narrative Identity Work in Macro Work Role Transitions. Academy of Management Review, 35(1): 135-154.

Jay, J. 2013. Navigating Paradox as a Mechanism of Change and Innovation in Hybrid Organizations. Academy of Management Journal, 56(1): 137-159. 
Jones, C., Maoret, M., Massa, F. G., \& Svejenova, S. 2012. Rebels with a cause: Formation, contestation, and expansion of the de novo category "modern architecture," 1870-1975. Organization Science, 23(6): 1523-1545.

Kapner, S. 2009. Liz Claiborne's extreme makeover. Strategic Direction, 25(5). https://doi.org/10.1108/sd.2009.05625ead.004.

King, B. G., Clemens, E. S., \& Fry, M. 2010. Identity Realization and Organizational Forms: Differentiation and Consolidation of Identities Among Arizona's Charter Schools. Organization Science, 22(3): 554-572.

King, B. G., \& Whetten, D. A. 2008. Rethinking the Relationship Between Reputation and Legitimacy: A Social Actor Conceptualization. Corporate Reputation Review, 11(3): 192-207.

Kraatz, M., \& Block, E. S. 2017. Institutional Pluralism Revisited. In R. Greenwood, C. Oliver, T. Lawrence, \& Meyer R. (Eds.), The Sage Handbook of Organizational Institutionalism. London: Sage Publications. London: Sage Publications.

Kraatz, M. S., \& Flores, R. 2015. Reinfusing Values. In M. S. Kraatz (Ed.), Institutions and Ideals: Philip Selznick's Legacy for Organizational Studies, vol. 44: 353-381. Emerald Group Publishing Limited.

Kraatz, M. S., Ventresca, M. J., \& Deng, L. 2010. Precarious Values and Mundane Innovations: Enrollment Management in American Liberal Arts Colleges. Academy of Management Journal, 53(6): 1521-1545.

Krygier, M. 2015. Selznick’s Hobbesian Idealism: Its Nature and Its Origins. Institutions and Ideals: Philip Selznick?s Legacy for Organizational Studies, vol. 44: 21-52. UK: Emerald Group Publishing Limited. 
Lachowski, S. 2012. It's the Journey not the Destination. Values in Life and Business. Guide to Management by Values. Amazon Digital Services.

Lawrence, P. R., \& Lorsch, J. W. 1967. Differentiation and Integration in Complex Organizations. Administrative Science Quarterly, 12(1): 1-47.

Lawrence, T. B., \& Suddaby, R. 2006. Institutions and Institutional Work. In S. Clegg, C. Hardy, \& W. Nord (Eds.), Sage Handbook of Organization Studies (2nd ed.): 215-254. London: Sage.

Levinthal, D., \& Rerup, C. 2006. Crossing an Apparent Chasm: Bridging Mindful and LessMindful Perspectives on Organizational Learning. Organization Science, 17(4): 502513.

Loizos, C. 2017, December 12. Facebook bats back after a second former exec accuses it of negatively impacting society. TechCrunch. http://social.techcrunch.com/2017/12/12/facebook-bats-back-after-a-second-former-execaccuses-it-of-negatively-impacting-society/.

Lounsbury, M. 2007. A Tale of Two Cities: Competing Logics and Practice Variation in the Professionalizing of Mutual Funds. Academy of Management Journal, 50(2): 289-307. March, J. G. 1991. Exploration and Exploitation in Organizational Learning. Organization Science, 2(1): 71-87.

March, J. G., \& Simon, H. A. 1958. Organizations. Oxford, England: Wiley. http://psycnet.apa.org/psycinfo/1958-15040-000.

Marquis, C., \& Lounsbury, M. 2007. Vive la résistance: Competing logics and the consolidation of US community banking. Academy of Management Journal, 50(4): 799. 
Marquis, C., \& Tilcsik, A. 2016. Institutional Equivalence: How Industry and Community Peers Influence Corporate Philanthropy. Organization Science, 27(5): 1325-1341.

Martyn, A. 2016, November 25. Exxon's investors sue energy giant for downplaying climate concerns. Consumer Affairs. https:/www.consumeraffairs.com/news/exxons-investorssue-energy-giant-for-downplaying-climate-concerns-112516.html.

McGrath, R. G. 1999. Falling forward: Real options reasoning and entrepreneurial failure. Academy of Management Review, 24(1): 13-30.

McGrath, R. G. 2015, January 10. 15 years later, lessons from the failed AOL-Time Warner merger. Fortune. http://fortune.com/2015/01/10/15-years-later-lessons-from-the-failedaol-time-warner-merger/.

McMullen, J. S., \& Shepherd, A. 2006. Entrepreneurial action and the role of uncertainty in the theory of the entrepreneur. Academy of Management Review, 31(1): 132.

McMullen, J. S., \& Warnick, B. J. 2016. Should We Require Every New Venture to Be a Hybrid Organization? Journal of Management Studies, 53(4): 630-662.

Meyer, J. W., \& Rowan, B. 1977. Institutionalized Organizations: Formal Structure as Myth and Ceremony. The American Journal of Sociology, 83(2): 340-363.

Miles, R. E., Snow, C. C., Meyer, A. D., \& Coleman, H. J. 1978. Organizational Strategy, Structure, and Process. The Academy of Management Review, 3(3): 546-562.

Miller, D., \& Friesen, P. H. 1984. A longitudinal study of the corporate life cycle. Management Science, 30(10): 1161-1183.

Miller, T. L., Grimes, M. G., McMullen, J. S., \& Vogus, T. J. 2012. Venturing for Others with Heart and Head: How Compassion Encourages Social Entrepreneurship. Academy of Management Review, 37(4): 616-640. 
Mintzberg, H., \& Waters, J. A. 1985. Of strategies, deliberate and emergent. Strategic Management Journal, 6(3): 257-272.

Mishina, Y., Pollock, T. G., \& Porac, J. F. 2004. Are More Resources Always Better for Growth? Resource Stickiness in Market and Product Expansion. Strategic Management Journal, 25(12): 1179-1197.

Moore, J. H., \& Kraatz, M. S. 2011. Governance Form and Organizational Adaptation: Lessons from the Savings and Loan Industry in the 1980s. Organization Science, 22(4): 850-868.

Nohria, N., \& Gulati, R. 1996. Is slack good or bad for innovation? Academy of Management Journal, 39(5): 1245-1264.

Ocasio, W. 1997. Towards an attention-based view of the firm. Strategic Management Journal, 18(1): 187-206.

Ocasio, W. 2011. Attention to Attention. Organization Science, 22(5): 1286-1296.

Pascale, R. T. 1999. Surfing the Edge of Chaos. Sloan Management Review, 40(3): 83-94.

Pearce, J. A., \& David, F. 1987. Corporate mission statements: The bottom line. The Academy of Management Executive, 1(2): 109-115.

Perrow, C. 1972. Complex organizations a critical essay. Glenview Ill.: Scott Foresman.

Pfeffer, J. 1973. Size, Composition, and Function of Hospital Boards of Directors: A Study of Organization-Environment Linkage. Administrative Science Quarterly, 18(3): 349-364.

Pfeffer, J. 1992. Managing with Power: Politics and Influence in Organizations. Harvard Business Press.

Pfeffer, J., \& Salancik, G. R. 1978. The external control of organizations: a resource dependence perspective. New York: Harper \& Row. 
Plowman, D. A., Baker, L. T., Beck, T. E., Kulkarni, M., Solansky, S. T., et al. 2007. Radical change accidentally: The emergence and amplification of small change. Academy of Management Journal, 50(3): 515-543.

Poggi, J. 2010. Blockbuster's Rise and Fall: The Long, Rewinding Road. The Street. https:/www.thestreet.com/story/10867574/1/the-rise-and-fall-of-blockbuster-the-longrewinding-road.html.

Raffaelli, R., \& Glynn, M. A. 2014. Turnkey or Tailored? Relational Pluralism, Institutional Complexity, and the Organizational Adoption of More or Less Customized Practices. Academy of Management Journal, 57(2): 541-562.

Rao, H., Monin, P., \& Durand, R. 2003. Institutional Change in Toque Ville: Nouvelle Cuisine as an Identity Movement in French Gastronomy. American Journal of Sociology, 108(4): 795-843.

Regan, D. T. 1978. Attributional aspects of interpersonal attraction. In J. H. Harvey, W. Ickes, \& R. F. Kidd (Eds.), New directions in attribution research, vol. 2: 207-233. Hillside, NJ: Lawrence Erlbaum.

Rerup, C. 2009. Attentional Triangulation: Learning from Unexpected Rare Crises. Organization Science, 20(5): 876-893.

Rindova, V. P., \& Kotha, S. 2001. Continuous" morphing": Competing through dynamic capabilities, form, and function. The Academy of Management Journal, 44(6): 12631280.

Rousseau, D. M. 1995. Psychological contracts in organizations: Understanding written and unwritten agreements. Sage Pubns. 
Sarasvathy, S. 2001. Causation and effectuation: Toward a theoretical shift from economic inevitability to entrepreneurial contingency. Academy of Management Review, 26(2): $243-288$.

Schildt, H., \& Perkmann, M. 2016. Organizational Settlements Theorizing How Organizations Respond to Institutional Complexity. Journal of Management Inquiry, 26(2): 139-145.

Scott, W. R. 2000. Institutional change and healthcare organizations: From professional dominance to managed care. University of Chicago Press.

Selznick, P. 1957. Leadership in administration: a sociological interpretation.

Selznick, P. 1992. The moral commonwealth: social theory and the promise of community. Berkeley: University of California Press.

Selznick, P. 2000. On sustaining research agendas: their moral and scientific basis: an address to the Western Academy of Management. Journal of Management Inquiry, 9(3): 277-282.

Selznick, P. 2008. A Humanist Science: Values and Ideals in Social Inquiry. Palo Alto: Stanford University Press.

Shih, W. C., Kaufman, S. P., \& Spinola, D. 2007. Netflix. Harvard Business School Case 607138. http://www.hbs.edu/faculty/Pages/item.aspx?num=34596.

Short, J. C., \& Palmer, T. B. 2008. The application of DICTION to content analysis research in strategic management. Organizational Research Methods, 11(4): 727.

Siggelkow, N. 2001. Change in the presence of fit: The rise, the fall, and the renaissance of Liz Claiborne. Academy of Management Journal, 44(4): 838-857.

Siliciano, J. I. 1996. The Relationship of Board Member Diversity to Organizational Performance. Journal of Business Ethics, 15(12): 1313-1320. 
Sirmon, D. G., Hitt, M. A., \& Ireland, R. D. 2007. Managing firm resources in dynamic environments to create value: Looking inside the black box. Academy of Management Review, 32(1): 273-292.

Slevin, D. P., \& Covin, J. G. 1997. Strategy formation patterns, performance, and the significance of context. Journal of Management, 23(2): 189-209.

Sonenshein, S. 2010. We're Changing--or Are We? Untangling the Role of Progressive, Regressive, and Stability Narratives During Strategic Change Implementation. Academy of Management Journal, 53(3): 477-512.

Suchman, M. C. 1995. Managing Legitimacy: Strategic and Institutional Approaches. The Academy of Management Review, 20(3): 571-610.

Sutcliffe, K. M., Vogus, T. J., \& Dane, E. 2016. Mindfulness in Organizations: A Cross-Level Review. Annual Review of Organizational Psychology and Organizational Behavior, 3(1): $55-81$.

Swanson, E. B., \& Ramiller, N. C. 2004. Innovating mindfully with information technology. MIS Quarterly, 28(4): 553-583.

Teece, D. J., Pisano, G., \& Shuen, A. 1997. Dynamic Capabilities and Strategic Management. Strategic Management Journal, 18(7): 509-533.

Thietart, R.-A., \& Forgues, B. 1995. Chaos theory and organization. Organization Science, 6(1): 19-31.

Thomas, J., Clark, S., \& Gioia, D. A. 1993. Stategic Sensemaking and Organizational Performance: Linkages among Scanning, Interpretation, Action, and Outcomes. Academy of Management Journal, 36(2): 239-270. 
Thompson, J. D. 1967. Organizations in Action: Social Science Bases of Administrative Theory. New Brunswick NJ: Transaction Publishers.

Thornton, P. H. 2004. Markets from culture: Institutional logics and organizational decisions in higher education publishing. Stanford University Press.

Thornton, P. H., \& Ocasio, W. 1999. Institutional Logics and the Historical Contingency of Power in Organizations: Executive Succession in the Higher Education Publishing Industry, 1958-. AJS, 105(3): 801-843.

Thornton, P. H., Ocasio, W., \& Lounsbury, M. 2012. The institutional logics perspective: A new approach to culture, structure, and process. OUP Oxford.

Trout, J. 2005. Schizophrenia at GM. Harvard Business Review, 22.

Van de Ven, A. H., \& Poole, M. S. 1995. Explaining Development and Change in Organizations. Academy of Management Review, 20(3): 510-540.

Venkataraman, S. 2002. Stakeholder value equilibration and the entrepreneurial process. In R. E. Freeman \& S. Venkataraman (Eds.), Ethics and Entrepreneurship, vol. 3. The Society for Business Ethics.

Vogus, T. J., Rothman, N. B., Sutcliffe, K. M., \& Weick, K. E. 2014. The affective foundations of high-reliability organizing. Journal of Organizational Behavior, 35: 592-596.

Vogus, T. J., \& Sutcliffe, K. M. 2012. Organizational mindfulness and mindful organizing: A reconciliation and path forward. Academy of Management Learning \& Education, 11(4): 722-735.

Vogus, T. J., \& Welbourne, T. M. 2003. Structuring for high reliability: HR practices and mindful processes in reliability-seeking organizations. Journal of Organizational Behavior, 24(7): 877-903. 
Wald, E. R. 2017, April 15. Tesla Is A Battery Business, Not A Car Business. Forbes. https://www.forbes.com/sites/ellenrwald/2017/04/15/tesla-is-a-battery-business-not-acar-business/.

Walker, K., \& Wan, F. 2012. The harm of symbolic actions and green-washing: Corporate actions and communications on environmental performance and their financial implications. Journal of Business Ethics, 109(2): 227-242.

Weick, K. E. 1987. Organizational culture as a source of high reliability. California Management Review, 29(2): 112-127.

Weick, K. E., \& Sutcliffe, K. M. 2001. Managing the unexpected: assuring high performance in an age of complexity. Jossey-Bass.

Weick, K. E., \& Sutcliffe, K. M. 2006. Mindfulness and the quality of organizational attention. Organization Science, 17(4): 514-524.

Weick, K. E., Sutcliffe, K. M., \& Obstfeld, D. 1999. Organizing for high reliability: Processes of collective mindfulness. Research in organizational behavior, vol. 21: 81-124.

Whetten, D. A. 2006. Albert and Whetten Revisited: Strengthening the Concept of Organizational Identity. Journal of Management Inquiry, 15(3): 219-234.

Whetten, D. A., \& Mackey, A. 2002. A social actor conception of organizational identity and its implications for the study of organizational reputation. Business \& Society, 41(4): 393.

Wiengarten, F., Fan, D., Lo, C. K. Y., \& Pagell, M. 2017. The differing impacts of operational and financial slack on occupational safety in varying market conditions. Journal of Operations Management, 52: 30-45. 
Williams, T. A., \& Shepherd, D. A. 2016a. Building Resilience or Providing Sustenance: Different Paths of Emergent Ventures in the Aftermath of the Haiti Earthquake. Academy of Management Journal, 59(6): 2069-2102.

Williams, T. A., \& Shepherd, D. A. 2016b. Victim entrepreneurs doing well by doing good: Venture creation and well-being in the aftermath of a resource shock. Journal of Business Venturing, 31(4): 365-387.

Williams, T. A., \& Shepherd, D. A. 2018. To the Rescue!? Brokering a Rapid, Scaled and Customized Compassionate Response to Suffering after Disaster. Journal of Management Studies, 55(6): 910-942.

Williams, T., Gruber, D., Sutcliffe, K., Shepherd, D., \& Zhao, E. Y. 2017. Organizational Response to Adversity: Fusing Crisis Management and Resilience Research Streams. Academy of Management Annals, annals.2015.0134.

Wiltbank, R., Dew, N., Read, S., \& Sarasvathy, S. D. 2006. What to do next? The case for nonpredictive strategy. Strategic Management Journal, 27(10): 981-998.

Wry, T., Cobb, J. A., \& Aldrich, H. E. 2013. More than a Metaphor: Assessing the Historical Legacy of Resource Dependence and its Contemporary Promise as a Theory of Environmental Complexity. The Academy of Management Annals, 7(1): 441-488.

Wry, T., \& Zhao, E. Y. 2018. Taking Trade-offs Seriously: Examining the Contextually Contingent Relationship Between Social Outreach Intensity and Financial Sustainability in Global Microfinance. Organization Science, 29(3): 507-528.

Yunus, M. 2011, January 14. Sacrificing Microcredit for Megaprofits. The New York Times. 
Zajac, E. J., \& Westphal, J. D. 2004. The social construction of market value: Institutionalization and learning perspectives on stock market reactions. American Sociological Review, 69(3): 433-457.

Zott, C., \& Amit, R. 2010. Business Model Design: An Activity System Perspective. Long Range Planning, 43(2-3): 216-226. 


\section{Figure 1: Socio-cognitive Model of Mission Drift and Mission Work}

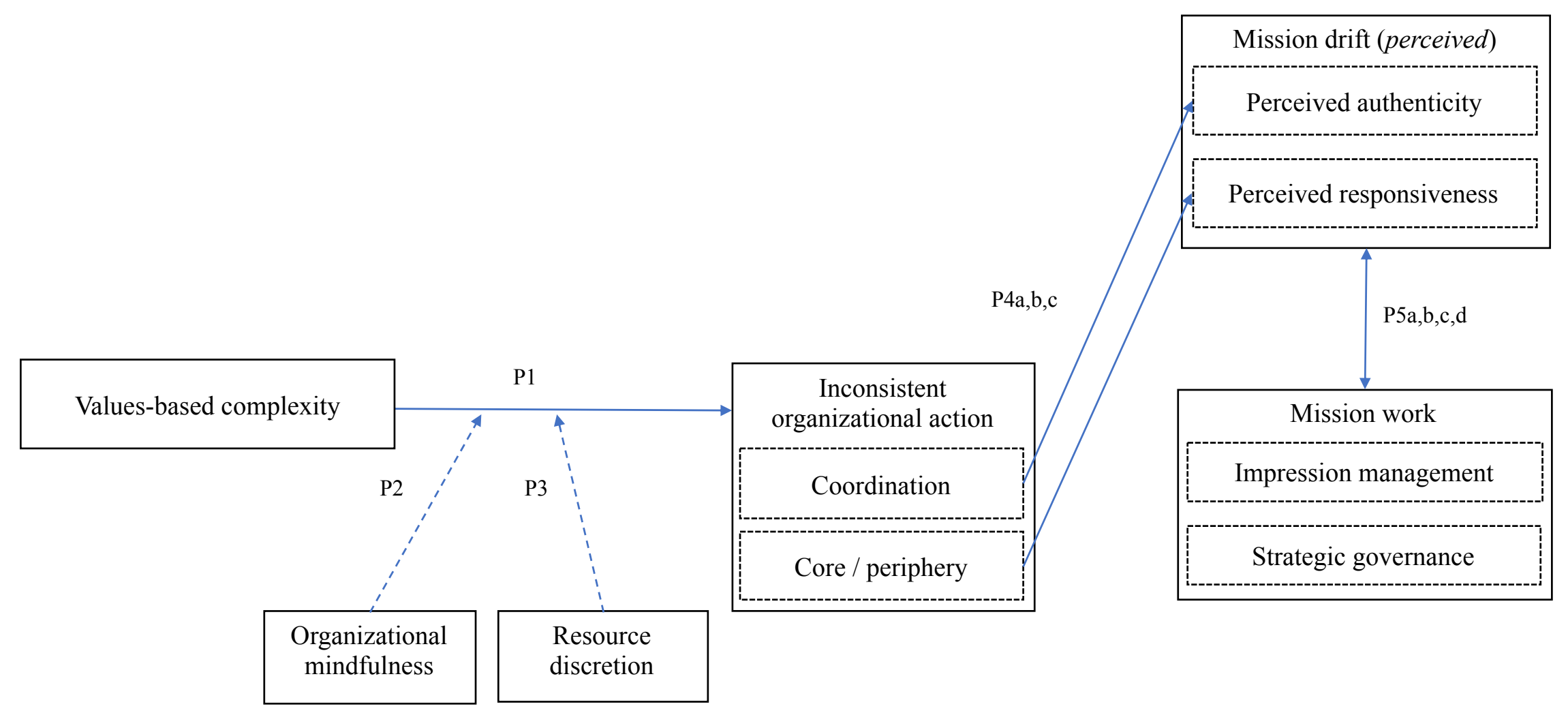




\begin{abstract}
About the Authors
Matthew G. Grimes (m.grimes@jbs.cam.ac.uk) is a reader in entrepreneurship and organization at the University of Cambridge's Judge School of Business. His current research focuses on the challenges of idea-stage entrepreneurship and social innovation.

Trenton A. Williams (trenwill@iu.edu) is an assistant professor of management and entrepreneurship at the Kelley School of Business, Indiana University. His research focuses on organizational emergence, venture resourcing under constraint, and hybridorganizing.
\end{abstract}

Eric Yanfei Zhao (ericzhao@indiana.edu) is assistant professor of management and entrepreneurship at the Kelley School of Business, Indiana University. His research focuses on bridging contemporary strategy and organization theories in addressing social innovation and entrepreneurship related topics. 